\title{
保存血流入速度遲延に関する研究
}

\author{
保存血血漿中に生じて来る血管収縮物質に就いて
}

東京大学清水外科（主任 清水健太郎教授）

高山良平

\section{STUDIES ON THESLOWING OF DRIP-RATE OF PRESERVED BLOOD TRANSFUSION-VASOCONSTRICTOR SUBSTANCE IN PRESERVED BLOOD}

\author{
by \\ Ryohei TAKAYAMA
}

The 1st Surgical Department of Tokyo University School of Medicine

(Director: Prof. Kentaro Shimizu)

\begin{abstract}
One of the practical disadvantages of preserved blood, compared with fresh blood, is the slowing down of transfusion drip rate. It is previously pointed out that this phenomenon is due to the venospasm, which occurs at the area proxismal to the site at which needle is inserted.

The author investigated the mechanism of this phenomenon, and obtained the results as follows.

1) The plasma of preserved blood causes contraction of the isolated strip of colon of the rat as well as the isolated spirally opened strip of the human vein.

2) Evidence is presented that this effect is not due to potassium, histamine, adrenaline, nor-adrenaline, acetylcholine or serotonin.

3) The active substance in the plasma was found to be released from $\alpha$-globulin fraction of plasma in the presence of destroyed platelets.

4) The yellowish active substance was obtained from the preserved plasma.

5) Preservation of whole blood in siliconized bottle to minimize the destruction of platelet is proved to be effective in preventing the production of the active substance.
\end{abstract}

$$
\text { 目次 }
$$

I. 緒 論
II. 保存血流入速度遅延の機構

III. 保存血血漿の静脈収縮現象
(1) 万法及び試料
（2）成績及び考按

VV. 保存血血墏のダイコクネズミ結腸の収縮現像
(1) 方法及び試料
（2）成績及び考按

$\mathrm{V}$ ．収縮物質の由来（1）

（1）血液成分分別法

（2）分別試料のダイコクネズミ結腸収繀能

（3）小括及び考按

VI. 保存血血獎及び分別試料のセロトニンの測定
（1）測定法の選沢
（2）分光螢光測定法
(3) 生物学的測定法
(4) L S D のセロトニン拮抗作用
（5）小括及び考按

VII. 収縮物質の由来（2）
（1）血獎蛋白分劃試料の作製
（2）血漿蛋白分劃試料のダイコクネズミ結腸収縮 能
（3）血漿蛋白分劃試料のセロトニン測定
（4）小括及び考按

VIII. 平滑筋収縮物質についての考察 
(1) Active Polypeptides 以外の1群

(2) Active Polypeptides の 1 群

（3）小括及び考按

IX. 本収縮物質の抽出

$X$. 本収縮物質の生化学的性質

（1）蛋白分解醅素に上る不活性化

（2）熱耐性

(3) 透析性

(4) ペーパークロマトグラフィー

（5）小括及び考按

XI．保存血流入速度遅延の対策

XII. 総括及び考按

YIII. 結 論

\section{I. 緒 論}

保存血には必要時に必要量が使えるという大き な利点がある反面に，色々な欠点もある，例え ば, 保存血輸血の生物的治療効果は種々の血液凝 固因子の不足を始めとする色々の因子に於いて, 新鮮血に及ばないという事が先ず問題であるし， 又保存血には細菌洉染の可能性の増大が大きな危 険の要素として加わつて来る. 更に早くから我々 が指摘している様に，保存血の流入速度が新鮮血 に比して遲延して，急速を要する輸血に支障を来 することがある，第一及び第二の問題について は，既に多くの研究がなされているが，第三の 流入速度遲延の問題については, 本邦に於て玍川 $(1953)^{63)}$ が始めて比の現象を発表し，其後田仲 (1954) 126$)$ の報告があるのみである. 外国の交献を 調査してみてもこの問題に関する研究は意外に少 く, 米国に於ては N.Neustrup (1951) ${ }^{95)}$ ， H.I. Lipson (1955) 70)，獨逸に於ては H. Schneider

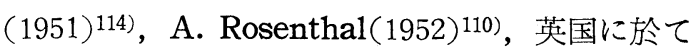
は G. Keyns (1949) ${ }^{74)}$, P.L. Mollison(1956) ${ }^{90)}$ の報告がみられるのみである、彼等はこの流入速 度遲延の原因として, (1)輸血セットの操作の不適 切及び故障の場合，(2)輸血用ゴム管又は輸血針の つまつた場合, (3)保存血の粘稠度の増加, (4)麻醉 及び手術操作による受血者静脈圧の上昇, (5)カニ ユーレの位置の不適当又は冷い保存血の急速注入 による受血者静脈の孪縮又はショック狀態の時の 静脈孪縮等を挙げている。これらの原因は，いず
れも物理的文は機械的因子に着眼しているのみで あり, 且つ田仲の保存血の溶血が主因であるとの 說も流入速度遲延の一因たり得ても主因ではない ことを，星川が誌上63)64)及び第15回医学会総会65) で発表し, 保存血血漿中に輸血部位の静脈を收縮 させる血管收縮物質が生じてくるものと推測し た. 師ち G. Keyns ${ }^{74)}$ はこの現象の原因の一つ として, natural tendency to slowing なるも のを挙げてこの本態は未だ不明であると述べてい るが，注目に價するものと考えられた。我々は保 存血自体の性狀の変化に注目して, 更に本現象を 追究した結果, 保存血血漿中に次第に生じて来る 血管收縮物質がこの現象の本態であるとの結論を 得て, 第 8 回日本輸血学会125) 及び第 8 回国際輸 血学会117)でその要旨を報告した。

\section{II. 保存血流入速度遅延の機構}

我国で保存血が使用されてから間もなく，手術 時に輸血を管理していた麻醉者から，「保存血輸 血では流入速度が遲く，時には全く停止してしま

図 1 臨床実験

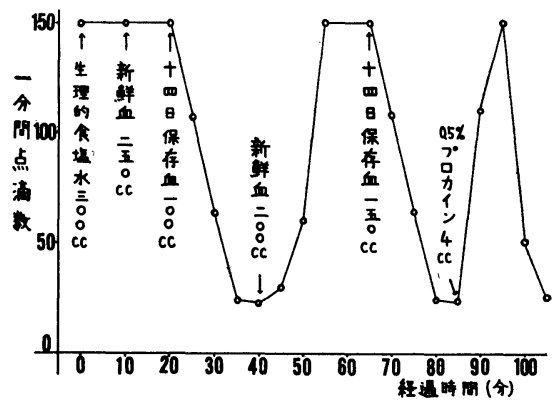

う」との欠点が強調せられた。特に当教室では脳 手術が多く, 短時間に大量輸血を必要とし, 且つ 輸血部位としては下肢の静脈よりの輸血が多かつ たために，特に流入速度が嘱く90)この問題が注目 された。

流入速度遅延つ状態を単位時間の点滴数で示し た臨床実験の一例が図 1 である，横軸は経過時間 を分で現し，綐軸は流入速度をコックを全開にし た場合の 1 分間の点滴数で示した。全く支障なく 流入している時は 150 滴又はそれ以上であるが， 150滴以上又は線狀をなして流入している時で 
も，図では 150滴として表現した。生食及び新鮮 血は 1 分間 150 滴又はそれ以上で順調に流入して いるが，14日保存血ではその速度が 5 分後に 108 滴, 10 分後には64滴と減少し, 15分後には24滴と 甚だしい減少を示した。このように流入速度遲延 を起した場合には, 輸血部位の静脈の中枢側が著 明に細くなり, 固い針金の如くなつている事が触 知される、郎ち著明な静脈收縮をおこしているこ とが想像される．この場合に新鮮血に切り替える と, 図の如く流入速度は次第に回復して順調に流 入し, 又塩酸プロカインをゴム管より注入する と，一過性ではあるが速かに流入する様になる。 この順調に流入している時は, 保存血輸血時に認 められた静脈收縮は緩解して, 針金の如き硬結は もはや触知されない。この静脈收縮が保存血流入 速度遲延の原因と考えられる. N. Neustrup,

A. Rosenthal, H.I. Lipson 及び P.L. Mollison は本現象の原因の一つとして静脈收縮を挙げてお り, 特に N. Neustrur ${ }^{95)}$ 及び H.I. Lipson ${ }^{70)}$ は保存血中にプロカインヌはプロカインアマイド を混入することが本現象の対策として有効である と報告してはいるが, 彼等は保存血が冷いという 物理的因子のみに着目し，これが静脈收縮を起す と述べているのみである。然しこれは星川(64)65)に よつて否定されている様に主因ではないようであ る.

保存血は保存中にその性狀に变化を生じてくる ことは充分に可能性があるのであつて, 保存血中 に静脈收縮を起す物質が生じ，これが血漿中に遊 漓してくるのではないかと推定される.この推定 の下に保存血から血漿のみを分離し, 血漿の流入 速度をみると, 保存血全血液と同じく著明な流入 速度遲姃を起した. 師ち保存血血漿中に, 静脈收縮 を起す物質が生じてくるのであると推測された。

\section{III. 保存血血漿の静脈収縮現象}

保存血輸血における輸血部位の静脈收縮を実証 するために, R.F. Furuchgott et al 等3)22)35)37) 52)53)83)128）の方法に従つて，剔出した人静脈の保 存血血漿による收縮をキモグラフィオンの煤紙に 描記せしめて観察した。
図 2 キモグラフィオン装置略図

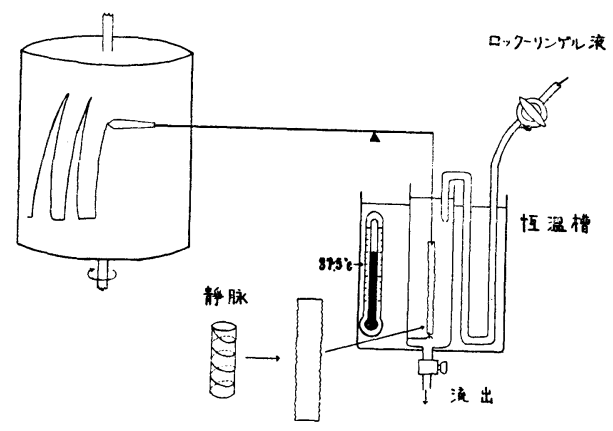

（1）方法及び試料

外傷や肉腫等で切断された人の下肢の中で損傷 や病変の全くない内顆部の大伏在静脈を約 $3.5 \mathrm{~cm}$ 切りとつた後, 輪狀筋の收縮をみるためにこれを 螺旋狀に切り図 2 の如く装置した。潅流液はロツ クーリンゲル氏液 (Locke-Ringer's solution)を 使用し, $37.5^{\circ} \mathrm{C}$ の恒温狀態で各種試料の收縮を描 記観察した。

新鮮血血漿は当日採血したA C D 加新鮮血より 又保存血血漿は20～30日保存のA C D加保存血よ り各々遠心分離して得た。 セロトニン註)・ノルア ドレナリン及びヒスタミン溶液はすべてロックー リンゲル氏液で $1 \mu \mathrm{g} / \mathrm{m} 1$ の濃度に稀釈して使用し た。

（2）成績及び考按

図 3 に示した如く, 明らかに保存血血漿に強い

図 3 剔出人静脈収縮キモグラム

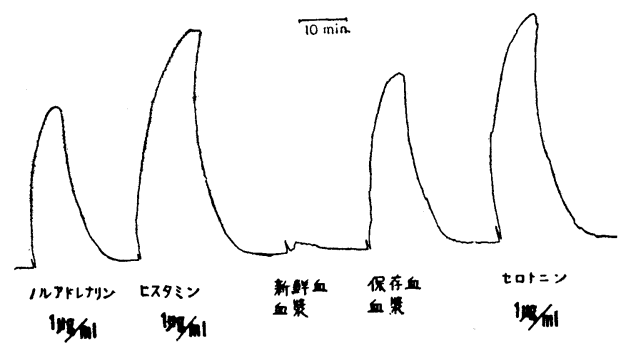

註）使用したセロトニンは, Nutritional Biochemicals Corporation, Cleveland Ohio o Serotonin creatinine sulfate $\varepsilon$, Upjohn Companyよりの Serotonin で, 後者は特に窒素 封入して安定性を保たせたものである. 
静脈收縮がみられ，新鮮血血漿には收縮がみれな w.

なおノルアドレナリン・ヒスタミン及びセロト ニンのいづれも著明な静脈收縮がみられた。同濃 度ではヒスタミンとセロトニンの收縮は,ノルア ドレナリンよりも強い傾向を示し，5例に於いて 全く同様な反応を呈した。又同時に，膝窩動脈を 用いて同じように收縮を検查すると, 静脈と同じ 收縮の傾向を示した，節ち保存血血漿中に，血管 壁平滑筋の能動的收縮を起す何らかの因子の存在 が確認せられた。従つて保存血はその保存中に変 化して，血管壁平滑筋收縮物質が血漿中に生じて くるものであるとの推測が成立するわけである.

然しこの保存血血漿中の血管壁平滑筋收縮物質 の生成並びに性質等の研究を進めるためには，人 静脈は材料として常に得難く，且つ定量的測定は 困難であるとの欠点がある，薬理学的に平滑筋收 縮作用を検討するには，通常種々の動物の平滑筋 組織が用いられているが，著者はダイコクネズミ の結腸を使用して保存血血漿の平滑筋收縮作用を 検討してみた。

\section{IV. 保存血血漿 のダイコクネズミ結腸 の 収縮} 現象

保存血血浆の平滑筋收縮作用をみるために, 操 作が簡単で且つ安定性のあるある剔出ダイコクネ ズミ結腸18)124)を使用して, 前述の静脈收縮と同じ く收縮狀態を観祭した。

(1) 方法及び試料

装置は前述と同じキモグラフィオンを使用した $100 \mathrm{gr}$ 前後のダイコクネズミを雌雄の別なく使 用した。 その上行結腸を盲腸の近くから約 $3 \sim 4$ cm切りとつて内容を洗滌し, 図 2 と同じく潅流液 中に垂直に懸垂した。㓷ち観察される收縮は，主 に縦走筋の收縮である，ダイコクネズミ結腸の自 発運動（spontaneous activity）を抑えるために は低温と潅流液中の $\mathrm{Ca}++$ の低濃度がよい18)

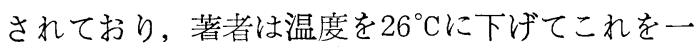
定にし，潅流液にはタイロード氏液（Tyrode's solution）の $\mathrm{CaCl}_{2}$ 量を $1 / 4$ に減らした修正夕 イロード氏液 (modified Tyrode's solution) を
図4 剔出ダイコクネズミ結腸収縮のキモグラム
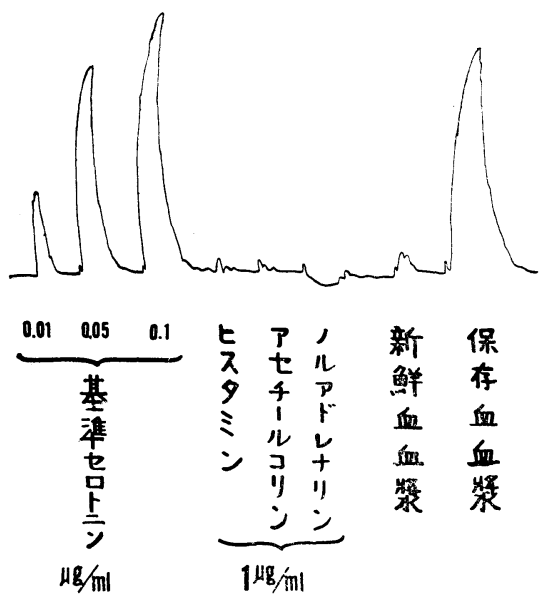

使用した．更にアセチールコリンによるダイコク ネズミ結腸の收縮を抑制するために，硫酸アト ロピンを潅流液に $1 \mu \mathrm{g} / \mathrm{ml}$ の割に加えた．新鮮血 及び保存血の血漿は, 修正夕イロード氏液で10倍 に稀釈して使用した。

\section{（2）成績及び考按}

四 4 に示した如く,ダイコクネズミ結腸でも新 鮮血血漿では殆んど收縮がみられないが保存血血 漿では強い收縮がみられる。文図にみられる如 く,ダイコクネズミ結腸はとスタミンには元来無 反応であり，アドレナリン及びノルアドレナリン では寧ろ扡緩し，アセチールコリンによる收縮 は，潅流液に加えられたアトロピンによつて抑制 されている.

師ち，保存血血漿中には血管と同じくダイコク ネズミ結腸をも收縮させる何等かの物質が生じ, 然もこれがアドレナリン・ノルアドレナリン・ヒ スタミン・アセチールコリンと異ることが証明さ れる。

\section{V. 収縮物質の由来 (1)}

保存血血漿中に生じてくる本收縮物質が, 血液 中のぞの成分に由来するのであるかを次の方法で 追究した。

\section{（1）血液成分分別法}

血液各成分の分別には, 各血液成分が無菌的且 つ純粋に，しかも充分量得られることが必要であ。 
図 5 血液各成分遠心分別法

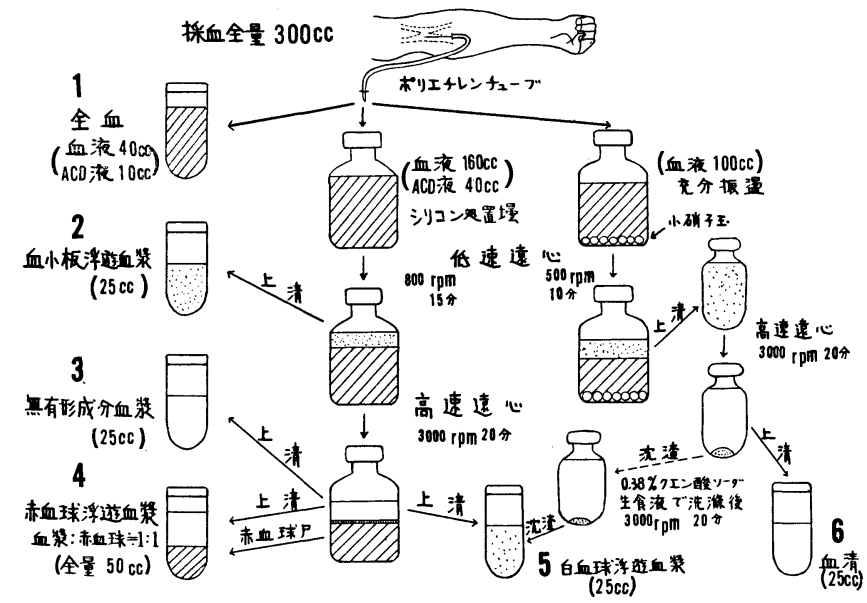

表 16 種試料血球数 $/ \mathrm{mm}^{3}$ ( 8 例平均)

\begin{tabular}{|c|c|c|c|c|}
\hline & & 赤血球 & 白血球 & 血小板 \\
\hline & 全 血 & $370 \times 10^{4}$ & 5700 & $\frac{14.1 \times}{10^{4}}$ \\
\hline (2) & $\begin{array}{l}\text { 血 小板 } \\
\text { 浮遊血漿 }\end{array}$ & $\begin{array}{r}2.1 \times 10^{4} \\
\end{array}$ & 3400 & $\begin{array}{r}25.3 \times \\
10^{4}\end{array}$ \\
\hline (3) & $\begin{array}{l}\text { 無有形 } \\
\text { 成分血獎 }\end{array}$ & 0 & 0 & 0 \\
\hline (4) & $\begin{array}{l}\text { 赤血 球 } \\
\text { 浮遊衁漿 }\end{array}$ & $\begin{array}{r}420 \times 10^{4} \\
\end{array}$ & 350 & 0 \\
\hline (5) & $\begin{array}{l}\text { 香血 球 } \\
\text { 浮遊血漿 }\end{array}$ & 300 & 800 & 0 \\
\hline (6) & 血 & 0 & 0 & 0 \\
\hline
\end{tabular}

る.

四 5 の如く遠心法で血液中の各成分を，(2)血小 板浮遊血漿，(3)無有形成分血漿，(4)赤血球浮遊血 漿，(5)白血球浮遊血獎，(6)血清の5 種類の試料に 分け，更に(1)全血液を併せて合計 6 種試料を作製 した.この 6 種試料 8 例の血球数を算定し, その 平圴值を表 1 に示した。赤血球数は Hayem 氏 液, 白血球数は Türk 氏液, 血小板数は Sequestrene 液11)48)931129)を用いて直接法で算定した。

最も破壊され易い血小板の分别操作に対して は, 必要な器具にはシリコン処理（siliconized） し，採血管にはポリエチレンチューブを使用し た.シリコン及びプラスチックは所謂 nonwettable surfaceの特性を有し, 血小板の破壊を可及
的に防ぐといわれている. 45)60)61)85)91)122)130：シリ コン処理は次の如く行つた，信越化学工業のシリ コンKF 99， 1 容にベンゾール20容を加えて，充 分に清浄にした採血䭪及び注射針内面を洗い，2 $00^{\circ} \mathrm{C} 2$ 時間乾熱し, 更に蒸気滅菌を行つた。こ のように処理した採血境にAＣＤ加新鮮血を採血 し, 800rpm15分の低速遠心 51)66)91)を行つて, 血 小板浮遊血漿（platelet-rich plasma）を得た。

無有形成分血獎（cell-free plasma）は, 前述 の如く特に血小板の破壊を少くするために，シリ コン処理した器具で採血分離した血漿を意味す る.

白血球の純粋分離が最も困難である事は一般に 認められているが，著者の方法でも白血球收容量 は少く，多量の分離が望まれる本実験にはいささ か不充分ではあつた。木村75)方白血球の分離法を まとめて報告しているが，本奏験の性格より dextran その他の薬品の添加は收縮奏験に影響を与 える可能性があるので，著者は遠心法を採用し た.J.L. Tullis（1952)133)134）は特殊な遠心分離装 置で無菌的に95 99\%純度の白血球を分離してお り, 現在最も優秀な分離法とされているが，これ を行う事は本邦では未だ不可能である. その他最 近では P.Wildy et al (1958)149)の分離法がある が，操作の複雑な上に收量は結局 $19.8 \%$ 程度であ 
図6 6 種試料のダイコクネズミ結腸収縮能の变化

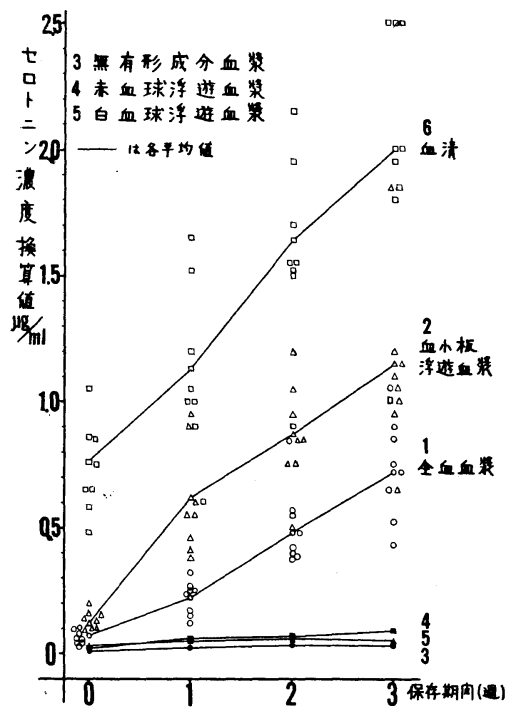

り，又川野（1958）72)の方法は赤血球に対する白 血球の割合がや〉上昇するとしている，以上によ り著者は図 5 の遠心法を採用して白血球の分離を 行つた。白血球沈渣の洗滌には，これが破壊され ることを可及的に少くするために，0.38\%クエン 酸ソーダ生食液で洗滌した。

（2）分別試料のダイコクネズミ結腸收縮能

この分別 6 種試料を $4{ }^{\circ} \mathrm{C}$ に保存して, 各々の血 漿又は血清について 3 週目迄 1 週間毎に，（IV） に述べたと局様の方法で剔出ダイコクネズミ結腸 の收縮能を測定した。この收縮能を兓知濃度のセ ロトニン基準液による收縮と比較して, 試料の收 縮能をすべてセロトニン濃度値に換算した。

図 6 に示す如く, 8 例之も全血の血漿・血小板 浮避血漿及び血清は, 保存日数と共にその收㴼能 が次第に増強したが，無有形成分血漿・赤血球浮 遊血漿・白血球浮遊血漿は最初から腸管收縮能は 殆んぞなく，又日数を経過しても殆んど増強しな w.

\section{（3）小括及び考按}

以上により本收縮物質は, 剔出ダイコクネズミ 結腸を保存日数の経過と共に次第に強く收縮さ せ，これは血小板の存在する血漿郎ち全血及び血
小板浮遊の各血嶈と，血小板が最初より強く破壊 され，その破壊産物が存在する血清のみに生じて くるようである。これに反して血漿・赤血球・白 血球は，それぞれ単獨では本收縮物質を作ること には関係がないものと考えられる．邲ちこの收縮 をおこす物質はとくに血小板に関係があることが 証明される. 又有形血小板が全く存在しない血清 の收縮能が保存日数と共に著しく増強することよ り，血小板中に存在する收縮物質が，血小板の崩 壊と共に単に遊離して来ただけの為ではなく，血 小板中に存在するある物質が血清中に於いて日数 の経過につれて腸管收縮物質を次第に作り出して 来るものと考えるのが妥当である．

なお（III）及び（IV）に於いて，保存血血漿は 新鮮血血漿と違つて剔出人静脈と同様にダイコク ネズミ結腸をも強く收縮させることを述べたが， この保存21日目の分別試料の中, 腸管收縮能を増 強した血清と何等増強しない無有形成分血漿で,

（III）と同様の方法で剔出人静脈の收縮を測定す ると血清ではこれを強く收縮し無有形成分血漿で は何等收縮を起さないことが観察された。師ち本 收縮物質の平滑筋收縮作用は，人静脈とダイコク ネズミ結腸に対しては大体平行するものと思わ れ，保存血血漿の血管收縮作用を研究していく上 に，平滑筋材料としてダイコクネズミ結腸を使用 して検討し得るものと思われる。

\section{VI. 保存血血漿及び分別試料のセロトニンの測} 定

血清は血漿と違つて，非常に強い血管收縮作用 のあることは古くから知られており， Ludwig， Schmidt（1868）の観察が最初であるといわれ， 更に O’Conner (1912) が現在のセロトニンと考 えられるものを報告している. その後 T.C. Janeway et al (1918）68)の報告がみられるが，この 血管收縮作用は血小板数と汪ぐ比例することを広 瀬 (1918) ${ }^{59)}$ が報告している. I.H. Page et a1104) 105)106) 107) は血液中に存在する血管收縮物質をもと めて，1948年に遂にセロトニンを得た血液中のセ ロトニンは源を腸管の enterochromaffin cells ${ }^{31}$ に発し，血液中では血小板に含まれ，正常では血 
漿中のセロトニン量は零であるといわれている66) 76) 80)96) 102).

著者はまず，保存血血墏中で次第に血小板が破 㙥されてセロトニンが堌加し，これが静脈を收縮 させ, 流入速度遲莚の原因となると推測し, 保存 血血漿のセロトニン量を測定した。

（1）測定法の選擇

セロトニンの測定には, 現在次の 5 つの方法が 用いられている。

1) 生物学的測定法 (Biological assay)

2) 紫外線吸收法（Ultraviolet absorption method)

3) 比色定量法 (Colorimetric assay)

4) ペーパークロマトグラフィー (Paperchromatography)

5）分光䖝光測定法 (Spectrophotofluorometric assay)

血漿中のセロトニン量は脳・腸管等の組織に含 まれているそれと比較して非常に少く，1)及び5） の方法を除いては血漿中のセロトニン量の測定は 殆んど不可能である。師ち，紫外線吸收法では $0.4 \mu \mathrm{Mole} / \mathrm{ml}$ が最低必要量で, $0.04 \sim 0.4 \mathrm{Mo}$ le 濃度のセロトニン測定に適し138), 比色定量法は 紫外線吸收法とほぐ同程度の0.05〜 $0.8 \mu \mathrm{Mole}$ を必要とする138).ペーパークロマトグラフ ィ法29) では，最も鋭敏といわれる Ehrlich 試薬で発色 させても $3 \sim 10 \mu \mathrm{g}$ のロトニンを必要とする123). 師ち 2）3）4）の方法では，セロトニン測定の限 界は $5 \sim 50 \mu \mathrm{g} / \mathrm{ml}$ の高濃度のセロトニンを必要 とするわけである. 血中の正常セロトニン量は, 血清で $0.044 \sim 0.247 \mu \mathrm{g} / \mathrm{ml}$, 平均 $0.1 \mu \mathrm{g} / \mathrm{ml}^{100}$ ) 119) 全血では $0.16 \mu \mathrm{g} / \mathrm{ml}$ の價が報告されてい る. 血小板のセロトニン量は, $0.3 \mu \mathrm{g}$. platelet serotonin $/ \mathrm{mg}$ platelet protein（但し正常血中の 血小板蛋白量は 0.3〜 $1.0 \mathrm{mg} / \mathrm{ml}$ ) 位とされてい る.いづれにしても血漿中に生じ得るセロトニン 量は, 最大 $0.1 \sim 0.3 \mu \mathrm{g} / \mathrm{ml}$. である. 以上の理 由から, 生物学的測定法を除いては最も鋭敏であ る分光螢光測定法で, 保存血血漿中のセロトニン 量を測定した。
図 7

\section{Spect rophot of luorometer \\ (分光䇺光光度計)}
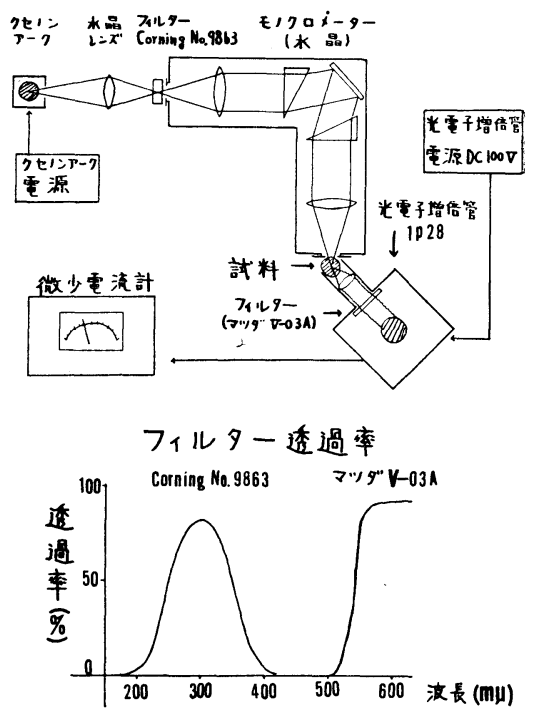

（2）分光螢光測定法10)138)139)

セロトニンは強酸性下では, $295 \mathrm{~m} \mu$ の励起光 をあてると $550 \mathrm{~m} \mu$ の螢光を発し， $0.01 \mu \mathrm{g} / \mathrm{ml}$ の微量濃度でも測定可能といわれる. 著者は東京 大学物性研究所の牧島研究室の図 7 に示した Spectrophotofluorometer を使用して, 保存血血漿 中のセロトニン量を測定した。

この測定で用いられるセロトニン抽出法は, 硫 酸亞鉛除蛋白法140) とブタノール抽出法140) が用い られている。但し両者の抽出法は, いづれもセ ロトニン濃度が $0.5 \mu \mathrm{g} / \mathrm{ml}$ 以上であることを必 要とし, 正常血漿中のセロトニン量の如く非常 に低い濃度では, この二つの抽出法の併用がよい とされている140)，著者は大量の血漿を用いて，硫 酸亞鉛除蛋白法とブタノール抽出法を併用して次 の如き抽出を行つてセロトニンを測定した。

抽出法：血漿20ccに10\% $\mathrm{ZnSO}_{4} \quad 15 \mathrm{cc}$ を加えて 充分混和し，この混合物に $1 \mathrm{~N} ・ \mathrm{NaOH} 7.5 \mathrm{cc}$ 加 えて $3000 \mathrm{rpm}$ で15分遠心する.上清を他の遠心 管に移し、これに無水炭酸ソーダを加えてpHを約 10に調節する。これにpH10の唧酸バッファー註1) 5 ccを加え，更に NaCl10gr と n-ブタノール註2) 
15ccを加えて10分間振擝する。これを3000 rpm で15分遠心した後，ブタノール相を他の遠心管に 移して再び上記硼酸バッファーを15cc加えて10分 間振盪する。 バッファー相を吸引除去後, 残つ たブタノール相に20CCヘプタン註3) と $0.1 \mathrm{~N} \cdot \mathrm{HCl}$ $1.5 \mathrm{cc}$ 加えて再び10分間振盪する. $3000 \mathrm{rpm} て ゙$ 15分遠心した後上清を吸引除去し，残つた酸層

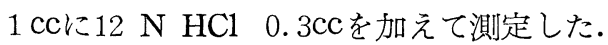

以上の操作によるセロトニンの recovery は35 〜 65\%で，かなり低く且つ不定ではあつたが，保 存血血漿中のセロトニン量は増加することなく, 寧ろ減少することを知ることが出来た。ペーパー クロマトグラフィーを用いて保存血の血小板中の セロトニンの減少を渋沢115) が，保存血血清のセ ロトニンの減少を徳沢132) が報告しているが，更 に著者はセロトニン定量の正確を期すために，最 も鋭敏な生物学的測定法を行つた。

（3）生物学的測定法

交献的には，1)各種軟体動物の心臓及び足糸等 33)42)86)136)142)143)144)，2）家鬼耳豰血管潅流法97), 3)牛及び羊の頸動物脈切片7)150)，4)ダイコクネズ ミの胃141)，5）ダイコクネズミの子宮25)26)27)82), 等の色々の方法が報告されているが，（IV）に述 べた方法と全く同じく，Dalgliesh et al の剔出 ダイコクネズミ結腸18)43(67)73)124)を用いて測定し た.この方法は Z. Supek et al124)が報告してい る如く，操作が簡単で安定性があり，且つ定量 的愦差が少い利点がある。セロトニンの抽出には アセトン抽出法2)16)28)51)81)98)131)136)を用いた。

セロトニンのアセトン抽出法については議論も 多く, 抽出組織の種類, セロトニン量並びに組織 中の抽出阻止物質の性質によつて, 抽出され得る セロトニンの recovery が異つてくるといわれて いる. P. Correale (1956) 16)は脳組織中のセロ トニン抽出の recovery は低く且つ不定であると 述べ, 又 C.C. Toh (1954) 131)及び R.H. Hardisty et al (1955) 51) は全血中のセロトニン抽出 の recovery は非常に低く,これは red cell debrisによつてセロトニンの吸收或いは不活性化に 多分よるものであろうと述べている． C. Thom- pson et al (1958) ${ }^{127)}$ は全血のセロトニン抽出 で,ブタノール法を変形してこれを行つたところ， その recovery は73\%で満足すべき方法であると 提案している。然し脳・腸管及び全血と違つて, 血漿中のセロトニンのアセトン抽出法では, その recovery はよいとされており51)，著者は次の方 法で行つたが， recovery は80〜90\%で満足すべ きものであつた。

抽出法：アセトン註4) 4 容に試料 1 容をゆつく りと滴下し, 密閉して $4{ }^{\circ} \mathrm{C} て ゙ 24$ 時間保存する. 東 洋濾紙 (No.6 Ash 0.0006) でこの混合物を濾過 し, 更にアセトン少量で濾紙内面を洗い, 濾夜に

図86 種試料のセロトニン濃度の低下

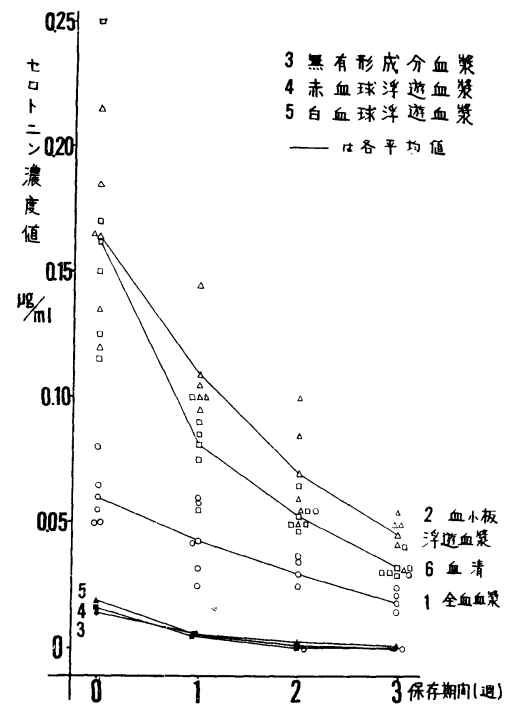

試薬はすべて特級を, 水は再蒸溜水を使用して次の 如く精製した。

註 i) 研酸バッファー（Borate buffer solution）： 硼酸 31.4 , 水 $1,10 \mathrm{~N} \mathrm{NaOH} 55 \mathrm{cc}$ の溶液に, 註 2) の如く精製した $\mathrm{n}$-ブタノールと $\mathrm{NaCl}$ を過剩に加党て充分振蕰する。n-ブタノールは 吸引は吸引除去し, 余分の $\mathrm{NaCl}$ はそのま〉 とする。最終 $\mathrm{pH} 10$.

註 2) ブタノール (n-Butanol) : ブタノールに等 量の $0.1 \mathrm{~N} \mathrm{NaOH}$ を加えて充分振盪し，こ机

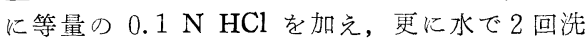
滌する。

註 3) ヘプタン（Heptane）：ブタノールと同様に精 製する。

註 4）アセトン (Acetone) : 再蒸溜する。 
加える，濾液を $40^{\circ} \mathrm{C}$ 以下で乾燥するが，あまり完 全に乾燥させないように注意する82)。乾燥後修正 タイロード液を原試料の 5 倍量を加えて剔出ダイ コクネズミ結晹の收縮を測定した。

$\mathrm{V}$ の分別 6 種試料の 5 例について, 保存日数の 経過につれてセロトニン量を測定した。図 8 に示 した如く，全試料のセロトニン量壮次第に減少 し，全血血漿では 2 週間目で㼛に測定上零となる ものもある。

(4) L S Dのセロトニン拮抗作用

セロトニンの平滑筋收縮作用は, LSD (Lysergic acid diethylamide ${ }^{34) 38,39,41)}$, BOL (2-Bromolysergic acid diethylamide ${ }^{12) 120)}$ エルゴタミン 及びギヒドロエルゴタミン51)115)等によつて，特 異的に阻止されるといわれている。著者はL S D 註)を使用して前述の分別試料及び前述アセトン抽 出試料の剔出ダイコクネズミ結腸收縮作用に対す る阻止效果を検討した。平滑筋收縮阻止作用に対 するL S D量とセロトニン量の関係は, 平滑筋の 種類によつて差があり，ダイコクネズミ子宮に対 しては，LSDのセロトニン拮抗作用は非常に効 果的であるとされている38)，剔出ダイコクネズミ 結腸のセロトニン收縮作用に刘しては, 著者の行 つた範囲では，L S D $0.1 \sim 0.5 \mu \mathrm{g} / \mathrm{ml}$ 濃度 10 分 間投与で，セロトニン $0.1 \mu \mathrm{g} / \mathrm{ml}$ に対する阻止効 果が充分現われた。

図9 に示した如く，基準液セロトニン及びアセ

図 9 L S D の拮抗作用キモグラム

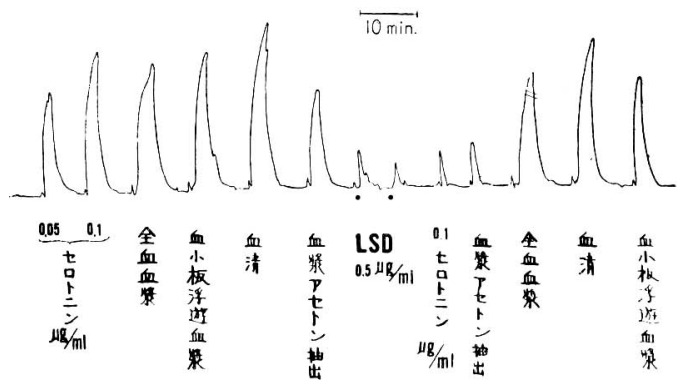

註) LSD: California Corporation for Biochemical Research, Los Angeles of D-Lysergic Acid Diethylamide Tartrate, C-grade 使用。
トン抽出試料は，ＬＳＤによつて腸管收縮作用が 明らかに阻止されたが，21日保存の血清・血小板 浮遊血嶈・全血血漿の腸管收縮作用注殆んご阻止 されず，阻此されても僅少に週きない，師ち著者 の測定している圾料のアセトン抽出物質はセロト ニンであると証明出来，父保存中に腸管收縮作用 を増強した本收縮物質は，セロトニン以外のもの であることが明らかに訨明出来る。

（5）小括及び考按

（V）に述べた如く保存血血墏中に次第に生じ てくる腸管收縮物質は，とくに血小板に関係が㐫 るが，血小板中に存在する強い平滑筋收縮作用の あるセロトニンは，著者の予想に反して，保存血 血漿中では逆に次第に減少した，更にセロトニン の平滑筋收縮作用を特異的に阻止するL S Dによ つては, 増強した保存血血漿の腸管收縮作用は阻 止されないことより，この收縮物質はセロトニン と異るものであることが訨明される。

\section{VII，収縮物質の由来 $(2)$}

血小板が破壞し，その破壞産物が血漿又は血清 に存在すると，本收縮物質が保存中に次第に生じ てくることが明らかになつたが，更に血漿蛋白分 劃の中，いゔれの分劃が收縮物質を生ずるに関係 するのであるかを検討するために，Cohn の血漿 蛋白分劃 ${ }^{13}$ 14)に血小板を加えて，（V）と同様に 保存して剔出ダイコクネズミ結腸の收縮能を測定 した。

（1）血漿蛋白分劃試料の作製 図10 Cohn の各血墏焦白分劃電気泳動図
Plasma

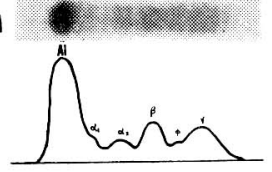

FN-4

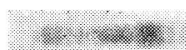

Fin+1II
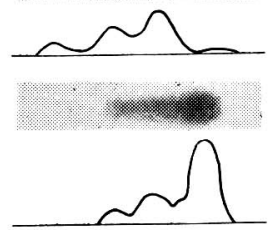

Fv

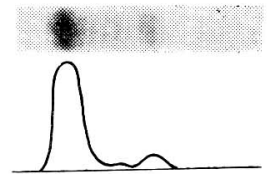

FN-1

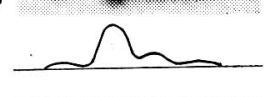

FII-3

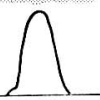


表 2 区10の電気泳動分析値\%（）内はCohn のオリヂナル

\begin{tabular}{|c|c|c|c|c|c|c|}
\hline & $\mathrm{Al}$ & $\alpha$ & $\beta$ & $\phi$ & $\gamma$ & 主 分 劃 \\
\hline 獎 & 55 & 10 & 14 & 5 & 16 & \\
\hline $\mathrm{F}_{\mathbf{v}}$ & $95(95)$ & $1(4)$ & $4(0.9)$ & $0(0)$ & $0(0)$ & $\mathrm{Al}$ \\
\hline $\mathrm{F}_{\mathrm{IV}-4}$ & $10(15)$ & $38(47)$ & $45(38)$ & $0(0)$ & $7(0)$ & $\mathrm{Al}, \alpha+\beta-\mathrm{Gl}$ \\
\hline FIV-1 & $7(0)$ & $81(88)$ & $11(9.8)$ & $0(0)$ & $1(2.0)$ & $\alpha$-Gl \\
\hline $\mathrm{F}_{\text {II }}+\mathrm{III}$ & $0(4.5)$ & $6(5.8)$ & $34(48)$ & $5(5.3)$ & $55(37)$ & $\alpha+\beta+\gamma-\mathrm{Gl}$ \\
\hline $\mathrm{F}_{\mathrm{II}-3}$ & $0(0)$ & $0(0)$ & $0(0)$ & $4(4)$ & $96(96)$ & $\gamma-\mathrm{Gl}$ \\
\hline
\end{tabular}

表 3 各分劃試料作製の計量及び各分劃の組成（ $\mathrm{g} / \mathrm{dl} ）$

\begin{tabular}{|c|c|c|c|c|c|c|}
\hline & 計量 & $\mathrm{A} 1$ & $\alpha$ & $\beta$ & $\phi$ & $\gamma$ \\
\hline 血墏 & $(7.5)$ & 4.13 & 0.75 & 1.05 & $\overline{0 .} \overline{37}$ & 1.20 \\
\hline $\mathrm{Fv}$ & 4.4 & 4. 18 & 0.05 & 0.17 & 0 & 0 \\
\hline $\mathrm{FIV}_{\mathrm{IV}}$ & 2.0 & 0.20 & $0 . \overline{76}$ & 0.90 & 0 & 0.14 \\
\hline $\mathrm{F}_{\mathrm{IV}}{ }_{1}$ & 1.0 & 0.07 & 0.80 & 0.11 & 0 & 0.01 \\
\hline$F_{I I}+I I I$ & 3.1 & 0 & $0 . \overline{19}$ & 1.05 & $0 . \overline{16}$ & 1.70 \\
\hline $\mathrm{F}_{\mathrm{II}}-{ }_{3}$ & 1.3 & 0 & 0 & 0 & 0.05 & 1.25 \\
\hline
\end{tabular}

使用した Cohn の血漿蛋白分劃は，日本製薬 中川氏より提供を受けたものである。図10はこれ の潇紙電気泳動図である. 泳動は $\mathrm{pH} 8.6, \mu=$ 0.05のベロナールバッファー, 東洋濾紙 No.51を 使用しい行い, B.P.B で染色後各分劃をデンシ

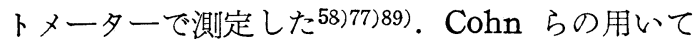
いる分劃の名称と電気泳動成分との関係は概略下 記のように対応すると考えてよい58).

F I ：フィブリノーゲン F II : $\gamma$-グロブリン F III : $\beta$-グロブリン F $\quad$ V $: \alpha$-グロブリン $\mathrm{FV}:$ アルブミン F VI : 残余の全部

この電気泳動分析值を示したものが表 2 であつ て，Cohn のそれとは多少の違いがあるが大差は ない，正常人血漿蛋白分劃は，10例の大略平均值 である。

この蛋白分劃の各々について, 最も多く含まれ ている分劃を主眼として，その分劃が正常血漿中 の同じ分劃と大体同濃度になるょうに生食で溶か し，各分劃試料を作製した。正常人血漿蛋白量は 日立血清蛋白計で測定 ${ }^{137)} し た 10$ 例の平均を，大 略 $7.5 \mathrm{~g} / \mathrm{dl}$ とした. 各蛋白分劃の計量及び出来 上つた試料の各分劃組成を, 表 3 に示した.

血小板は（V）に述べた如く，ポリエチレンチ
ューブ管及びシコリン処理した注射針と採血丵を 使用して採血した A C D加新鮮血より, 遠心法で

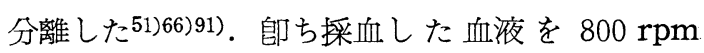
で15分低速遠心して上清の血小板浮遊血漿 (plateletrich plasma）を, シリコン処理した遠心管に 移し， $2500 \mathrm{rpm}$ で30分高速遠心し，上清を捨て 血小板沈渣を $0.38 \%$ クエン酸ソーダ生食液で洗策 し, 再び高速遠心して血小板沈渣を得た。こ〉に 得られた血小板数の算定は, 血小板相互の粘着凝 集のために測定困難であつたために，血小板の最 終 recovery 約 $1 / 3$ 位と見做して, 正常血液中 に存在する血小板数と大体同じ割合に各分劃試料 に血小板を加える目的を以て，300ccの血液を採 血してこれより血小板を分離し，これに対応する 各分劃試料の量を $15 \mathrm{cc}$ 位が適当であると計算し た。 そこで各分劃試料と対照とした生食液各 $15 \mathrm{cc}$ づつに，血小板をできるだけ均等になる様に加え た。

（2）血漿蛋白分劃試料のダイコクネズミ結腸 收縮能

図11に示したごとく，FV 及び FII-3 には收縮 の増強はなく寧ろ減少し, FIV-1 FIV-4に強い收 縮能の増強がみられ, 更に FII+IIIにも收縮能の 
図11 各分劃試料のダイコクネズミ結腸収縮能の変 化

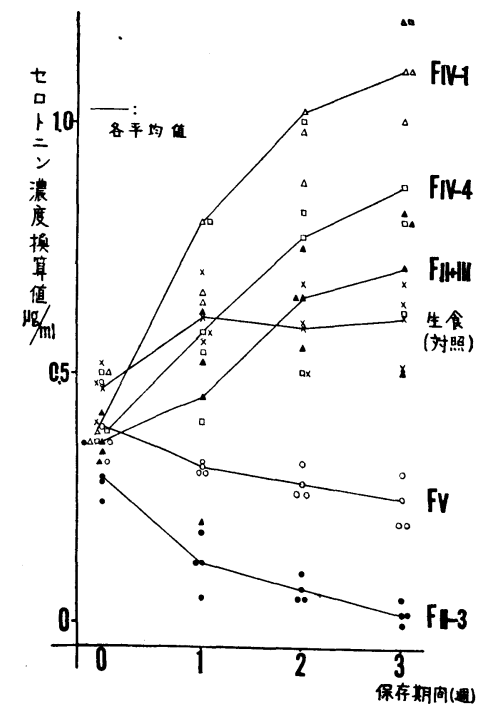

図12 各分劃試料のセロトニンの減少

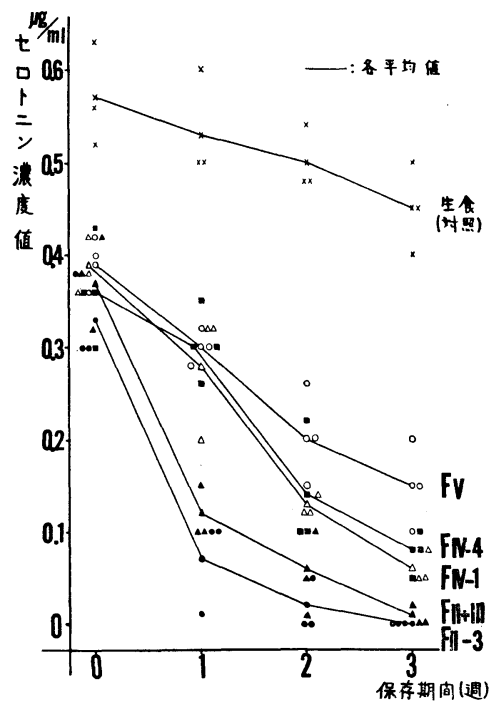

増強がみられた。対照生食液は收縮能の増強及び 減少があまりみられず, 大体一定の收縮能を維持 した.

（3）血漿蛋白分劃試料のセロトニン測定

この分劃試料のセロトニンを, (VI) と同様の 方法でアセトン抽出し, ダイコクネズミ結腸で測 定したのが図12である. 全試料のセロトニンは保
存日数の経過につれて減少した。然し生食液のセ ロトニン量の減少は少く, 他の蛋白分劃とはかな り異ることがみられる。

（4）小括及び考按

表 2 及び表 3 に示されておる如く, 主分劃がア ルブミン及び $\gamma$ グロブリンである FV 及び FII-3 には腸管收縮能の増強がないことより，アルブ ミン及び $\gamma$-グロブリンは本收縮物質の生成には あまり関係がないことは明らかである，腸管收縮

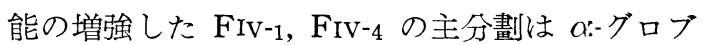
リンであり，又 FII-III \& $\alpha$-グロブリンの相当 量を含む. $\beta$-グロブリンは腸管收縮能の増强し た FIV-4,FIV-1，FII+III に含まれ，特にFII+III

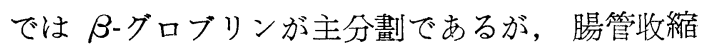
能の増強しないFVの ß-グロブリン量は, FIV-1 FIV-4 の $\beta$-グロブリン量よりも僅かではあるが 寧ろ多く含まれている. 以上の事より, 本收縮 物質の生成には $\alpha$-グロブリンが主に関係し血小 板破壊産物が 0 -グロブリンに作用して，本收縮 物質を作り出すものであると考えたい。

血中セロトニンは人体中では大体 1 時間半位で すべて交替する程代謝が速かなものとされている 30). 体内ではセロトニンは amine oxidas66)9)15) 113)118)153)によつて 5-HIAA (5-Hydroxyindole acetic acid) の形となつて排泄される. amine oxidase は体内に応く分布するが，血漿中にも amineaoxidase そのものか, 又はこれと類似し た作用のあるものによつて，七ロトニンは此較的 速かに破壊され，不活性化されるものと考えられ る。これに反して，生食液中にはこのような作用 のある酵素は当然存在せず, 為にセロトニンが比 較的長く破壊されずに存在するものであると推測 され，図11での生食液の維持している腸管收縮能 は，セロトニンによるものと考えられるのであ る.

更に各 Cohn の血漿蛋白分劃を生食で溶解し 血小板を加えないで $4{ }^{\circ} \mathrm{C}$ に保存し，2・4・6 日 後に血小板を加えて腸管收縮能を測定すると，い うれの分劃でも何等腸管收縮能の増強を認めず に，全例が減少の傾向を示した。Cohn の血漿蛋 
白分劃は乾燥狀態にあれば非常に安定であるが，

これが溶解されると不安定であり，凍結した血漿 蛋白はー $20^{\circ} \mathrm{C} に$ 於てさえも徐々に変性するといわ れている ${ }^{58)}$. 師ち血獎蛋白分劃中の本收縮物質を 作るに必要な因子は溶解狀態では変性し, 不活性 化され，收縮物質が生成されなくなるのではない かと考えられる。これらの点を考えあわせると， 血小板の破壊旁物と血墏中の收縮物質を作る因子 の作用機序は比較的早期に如まるものであり，し かもその増強はかなり緩徐なるものであると考え られる。以上によりこの收縮実験を行うために は，常に血小板を加える直前に分劃を溶解するこ とが必要である.

\section{VIII. 平滑筋収縮物質についての考察}

平滑笳を收縮させる物質は種々あるが，保存血 血漿中に出現してくる可能性のあるものは, Gaddum 等40)のいう活性ポリペプチド (active poly. peptides）の一群と，これ以外の一群に大別して 考えられる.

(1) Active Polypeptides 以外の一群

この中でとスタミン・アセチールコリン・アド レナリン・ノルアドレナリン及びセロトニンにつ いては，䠶に述べた如く本物質と関係が少ないこ とを明らかにして来た， $\mathrm{K}^{+}$は濃度によつて平滑 筋收縮物質となり得るし, 又これの血管作用24)も
図13 分別試料の濃度值

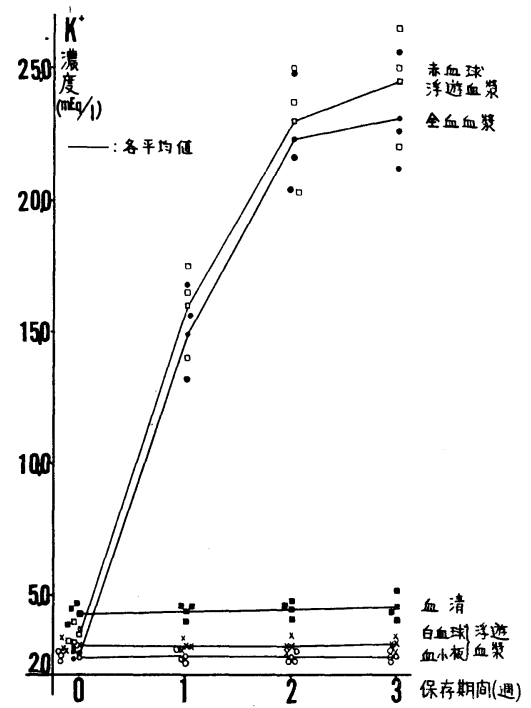

報告されている。保存血血漿中に遊離してくるK +は，殆んどが赤血球に由来するものである．即 ち溶血又は赤血球の透過性㐫進により赤血球中の $\mathrm{K}^{+}$は漸次血漿中に増加してくる21101)103)。（V ） の分別 6 種試料の中, 無有形成分血漿を除いた 5 種の試料の $\mathrm{K}^{+}$, 保存日数の経過につれて測定 した。測定法は日立熖光光度計で外部標準法によ つた152).

図13の如く, 保存血血漿中には勿論 $\mathrm{K}+$ は増加

表 4 Some Properties of Active Polypeptides

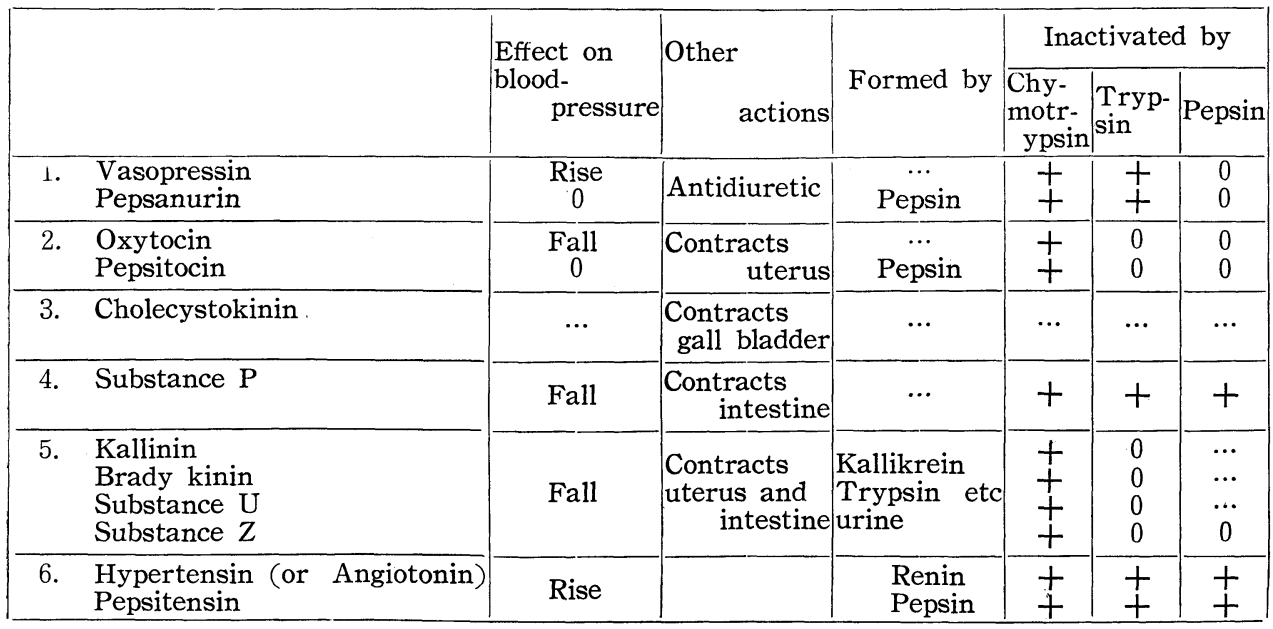


するが，何等腸管收縮能の増強しない赤血球浮遊 血漿でも同程度にK+は増加している，又收縮能 の飧く増強する血清及び血小板浮遊血漿では, 何 等 $\mathrm{K}+は$ 増加しない. 師ち腸管收縮能の増強と $\mathrm{K}^{+}$ 濃正は平行せず， $\mathrm{K}+$ は本收縮物質からは明らか に除外出来る.

アデノシン体 (adenosine compounds) の平 滑筋に対する作用については, 本邦に於ては藤田 36)の報告があり，保存血中のリン酸代謝について は, 吉川，中尾等94)151)の精しい報告がある。リ ン酸代謝は赤血球が主で，血小板とはあまり関係 がないものであるので, アデノシン体は本收縮物 質とは考えにくい.

本收縮物質は血小板と $\alpha$-グロブリンの相互作 用によつて生じてくることから，Gaddum 等の いう active polypeptides の一種と考えるには充 分なる根拠が存在する.

(2) Active Polypeptides の一群

現在迄知られている active polypeptides を Gaddum ${ }^{40)}$ は一応まとめて, 表 4 に示す如く薬理 学的性質に従つて分類している.

Vasopressin は G. Oliver and E.A. Schäfer (1895)によつて, Oxytocin は H.H. Dale (1906）によつて，共に下垂体後葉ホルモンとし て発見され, 殊に Oxytocin は現在合成されるに 至つている。

Cholecystokinin は A.C. Ivy and E. Oldbe rg（1928）によつて十二指腸粘膜層より, Substance P は腸管及び脳より U.S. Euler and J.H. Gaddum (1930) 32)によつて発見され, J.H. Gaddum and H. Schild (1934) 44)によつて Substance $\mathrm{P}$ と命名された. Cholecystokinin と Substance P との区別は不明で同一物質である可能 性もあるといわれている. 又 Substance P は血 小板中にも存在する67).

Kallidinは E. Werle el al (1937) 145)146)によ つて, Bradykinin は M. Rocha e Silva et al (1949）108)によつて発見された。これらは血漿 中の $\alpha_{2^{-}}$グロブリンに存在する Kallidinogen 又 は Bradykinogen に対して，前者には Kallikr- ein が，後者には Trypsin 又仿 Bothrops jararace の毒液が作用してそれぞれ Kallidin 及び Bradykinin が生じたものである. Substance U は W.T. Beraldo (1952) 6)により発見され, 尿 中のある酵素が $\alpha_{2}$-グロブリンに作用して生じ, Substance $Z$ は人尿中に存在することを， E. Werle and E.G. Erdös (1954) 148)が報告した。

Hypertensin (or Angiotonin) は J.M. Munoz et al (1939) ${ }^{92)}$ 及び I.H. Page et al (19 40) ${ }^{99)}$ によつて発見され， $\alpha_{2}$-グロブリンに存在す る Hypertensinogen に Renin が㗢いて生ずる といわれている.

Pepsanurin, Pepsitocin 及び Pepsitensin は, H. Croxatto et al (1942) 17)及び M.E. El lis et al (1949) 23)によつて報告されたが，い

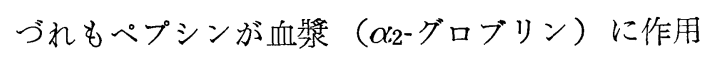
して生じたもので, 作用条件の違いで異なる性質 のポリペプチドを生じたものと考えられている.

以上の他に, Jaques et al (1954)69)112)は Common wasp (Vespa vulgaris) の毒液中に大 量の Kinin を発見しており,これは Bradykinin や Kallidin とは違つたポリペプチドであり 62), F.P. Gomes (1955) 46) は正常人尿中に, S.M. Hilton（1955）55)56)57) は唾液と血漿の作用 から生ずる Bradykinin 及び Kallidin に似たポ リペプチドを夫々報告し，更に D. Armstrong et al (1957） ${ }^{5)}$ は血漿が硝子表面に接触して生ず るポリペプチドを Pain Producing Substance として報告し，J. Margolis（1958）87)はこれの 生成の機構を詳細に発表している.

これらの数多いしかも複雑なポリペプチドにつ いて, 19576 月 Oxford で開かれた British Ph armacological Society で, J.H. Goddum 等は 血漿蛋白より生ずる Bradyklnin に似たポリペ プチドを一括して, Plasma Kinins ${ }^{84)}$ と命名す るのが適当であるとしている.

（3）小括及び考按

本物質の生成を考えてみると, Kallidin, Bradykinin 又は Hypertensin といつた所謂 Plasma kinins の生成の如く, $\alpha$-グロブリンに〜nog- 
en という様な物質があり, 血小板破壊産物の作 用をうけて, 〜gen というような active polypepideになり得ると考えても, 理論的には充分可能 性はあり得る，又 Kallidinogen に対する Kallikrein や, Bradykinogen に対する Trypsin 又 は B. jararaca の毒液, 更に Hypertensinogen に対する Renin の如き作用を，血小板破壊産物 がするものと考えたい，詳細な不明であるが，血 小板中に蛋白分解酵素が存在するとの報告もみら れる154).

本物質を active polypeptides の一種と考え て, この物質の性狀を追究し, Gaddum 等の記 載したそれと比較し，ぞのポリペプチドに類似す るかを次の諸点から研究した。

\section{IX. 本収縮物質の抽出}

本收縮物質は後述の如く熱に極めて安定である ので, D. Armstrong et al (1957)5)の方法で竟 沸除蛋白し，收縮物質を含む上清（Protein-free aqueous extract of plasma) を得た.

抽出法 A : 保存血血漿 1 容に修正夕イロード夜 3 容を加え, 時々振盪しながら者沸浴槽中で10分 間煮沸する，者沸すると次第に凝固が起る，その 後この混合物を流水で冷し， 2 N醋酸を加えて pHを 5 にし， $3000 \mathrm{rpm}$ で30分遠心する。この上 清をとり，2 N炭酸ソーダを加えてpHを 7.2 に戾 す.この上清は直ちに剔出ダイコクネズミ結腸の 收縮をみることが出来て，原血漿の腸管收縮能の 大体 $1 / 4$ 郎ち始めに稀釈した倍数に等しい腸管收 縮能を示した。この上清を乾燥させると, 收縮物 質を得るが非常に粗製であり，且つ乾燥されるに つれて酸性に傾き, pHの調節が困難となる。

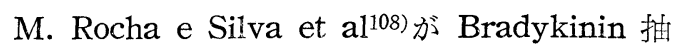
出に用いたアルコール抽出法は, その後他のポリ ペプチドの抽出に多少の修正が加えられて踏襲さ れておる5)62)。著者はこのアルコール抽出法によ つて，本收縮物質の抽出を試みた。

抽出法 B : 者沸した 2 容の純エタノールに保存 血血漿の 1 容を滴下し, 募沸浴槽中で 5 分間者沸 した後流水中で泠却し，3000rpm で 30分遠心す る.上清を $70^{\circ} \mathrm{C}$ 以下でへアドライヤーで乾燥した
後, 少量の蒸溜水で溶かし再び3000 rpm で30分 遠心して不溶性部分を除去した，上清を再び㢹燥 した後エーテル及びアセトンにて洗滌した後乾燥 した。こ〉で得られた乾燥抽出物質は, や〉泥狀 の淡黄色物質であつて，本法によるこの物質の抽 出 recovery は30〜35\%であつた。 未だ粗製物質 (Crude Substance) ではあつたが，この抽出 物質を使用して, 次に述べる本收縮物質の生化学 的性質を検討した。

\section{X. 本収縮物質の生化学的性質}

active polypeptides の各々の鑑別は, 生化学 的には收縮物質の蛋白酵素による不活性化, 熱耐 性，透析性等によつて行われている.

（1）蛋白分解酵素による不活性化

キモトリプシン註1)，トリプシン註2)，及びペプ シン註3）の 3 種類の酵素を使用し，本收縮物質の 不活性化を検討した。試料をキモトリプシンとト

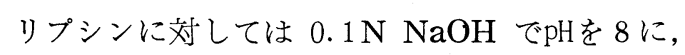
ペプシンに対しては $0.1 \mathrm{~N} \mathrm{HClでpHを} 2$ に調整し て, $10 \mathrm{mg} / \mathrm{ml}$ の割に各酵素を加え, $38^{\circ} \mathrm{C} て ゙ ~ 4$ 時 間作用させた後, $0.1 \mathrm{~N} \mathrm{HCl}$ 及び $0.1 \mathrm{~N} \mathrm{NaOH}$

表 5 蛋白分解酵素による本収縮物質の不活性化

\begin{tabular}{|c|c|c|c|c|c|}
\hline & $\begin{array}{l}\text { 保存 } \\
\text { 日数 }\end{array}$ & 試 料 & $\mid \begin{array}{l}キ モ \\
リ フ ゚ ~ \\
\text { リ } \\
ン\end{array}$ & $\mid \begin{array}{l}ト リ フ ゚ ~ \\
\text { シン }\end{array}$ & ペプシ \\
\hline & 11 & 全血血獎 & \pm & + & - \\
\hline & 18 & 11 & + & - & - \\
\hline & 24 & $\prime \prime$ & + & \pm & \pm \\
\hline & 25 & "I & + & + & - \\
\hline & 26 & $\prime \prime$ & + & + & - \\
\hline & 26 & "I & + & - & - \\
\hline & 27 & $\prime \prime$ & + & + & - \\
\hline & 30 & 11 & + & - & \pm \\
\hline & 36 & 11 & + & + & \pm \\
\hline \multirow{9}{*}{$\begin{array}{l}\text { 分別保 } \\
\text { 存試料 }\end{array}$} & \multirow{3}{*}{21} & 全血血漿 & + & \pm & - \\
\hline & & 血小板浮遊血漿 & + & + & - \\
\hline & & 血 清 & + & + & - \\
\hline & \multirow{3}{*}{21} & 全血血漿 & + & + & - \\
\hline & & 血小板浮遊血漿 & + & + & - \\
\hline & & 血 清 & + & + & - \\
\hline & \multirow{3}{*}{21} & 全血血獎 & + & \pm & + \\
\hline & & 血小板浮遊血獎 & + & \pm & + \\
\hline & & 血 清 & + & \pm & + \\
\hline
\end{tabular}


で逆に $\mathrm{pH} 7.2 に$ 戻し，原試料の10倍になるよう に修正タイロード夜を加えて，剔出ダイコクネズ ミ結腸の收縮を測定した。㕛酵素を加えないで同 じ操作を行つものを対照として比較した。こっで キモトリプシンで不活性化されることがポリペプ チドの最大特徴とされている.

最初試料として抽出操作を加えない保存血血漿 及び（V）の分別試料の中, 腸管收縮能を増強し た全血血漿，血小板浮遊血漿及び血清で，被酵素 作用を検討した。

表 5 に示した如く，キモトリプシンでは全部不 活性化されたが，トリプシンによつては全く態度 が不定であり，ペプシンでは大体不活性化されな い.なお対照は腸管收縮力に全く変化を来さなか つた.

酵素による不活性化の検討では，酵素自身も， 㕛作用を受ける物質も極めて純粋でないと結果が 一様でなく制定に苦しむと Gaddum は述べてい る. 特にトリプシン及びペプシンの場合には対照 より收縮が強い場合もあつて, 前述の Bradykinin や Pepsitensin 等の生因から考えて, トリ プシンスはペプシンによつて，これらの物質が 更に生じたとも考えられる。故に抽出法Bによつ て得た抽出物質について，被酵素作用を検討し た. 抽出物質をその recovery より逆算して原血 漿と同じ收縮力になるように修正タイロード液に とかし，これについて前述と同じょうに酵素を作 用させると，図14にみられるごとく，キモトリプ シン，トリプシンでは不活性化され，ペプシンで は不活性化されなかつた。

（2）熱耐性

active polypeptides はpH中性附近では一般に 熱に対して安定性であるといわれている，保存血 血漿及び抽出法Bによつて得た抽出物を修正夕イ

註 1) キモトリプシン (Chymotrypsid) ：持田製薬 株式会社の結晶キモトリプシン及び Nutritional Biochemicals Corporation, Cleveland Ohio の Chymotrypsin を使用.

註 2) トリプシン (Trypsin) : Merck Compay製を 使用

註 3) ペプシン (Pepsin)：＂，
図14 蛋白分解酵素による本収縮物質の不活性化キ モグラム

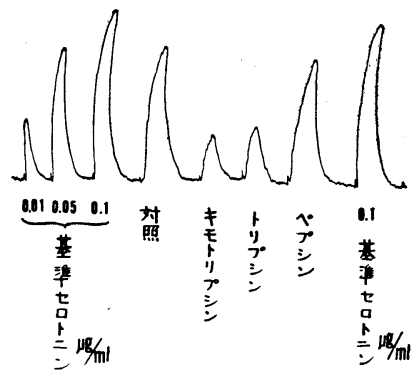

ロード液に稀釈又は溶解して煮沸浴槽中に入れ， 時間の経過を追つて剔出ダイコクネズミ結腸の收 縮能を測定した。抽出物の方は 4 時間位で初めて 收縮能の減少价みられた。師ち 4 時間位で漸次破 壊され始めるのであつて，熱に対しては安定であ るといえる，血漿の方は 6 時間位で初めて破壊さ れていつて，この遅れは血漿蛋白の熱保護作用に よるものであると考えられる。

（3）透析性

抽出物 Bによつて得た抽出物につき，大東セロ ファン No. 300 (厚さ18.7/1000mm) のセロフア ンで透析性をしらべた。抽出物を修正タイロー ド液に溶解してセロファンに入れ，この試料の 10 倍量の同じ修正タイロード夜中に浸し， $4{ }^{\circ} \mathrm{C} に$ 保 存してセロファ:内外液で剔出ダイコクネズミ結 腸の收縮を測定した。 4 時間では未だ透析され ず，24時間で内外液の收縮が等しくなつてくる. 師ち緩徐に透析されることが証明される，又この 透析性を利用して抽出物質を更に純粋化すること も可能である.

(4) ペーパークロマトグラフィ

抽出法 Bによつて得た抽出物を少量の蒸溜水に 溶かし，移動度（Rf）を検討した。展開液は $\mathbf{n}$ butanol-acetic acid-water ( $4: 1: 5)$, 滤紙は 東洋濾紙 No. 51 を使用し, 下降法で先端が $30 \mathrm{~cm}$ 移動する程度に室温で展開せしわた。原点から $3 \mathrm{~cm}$ 間隔で濾紙を切りとり, 各細片を夫々修正

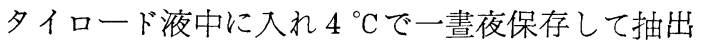
し, 剔出ダイコクネズミ結腸の收縮を測定した。 㘠15に示された如く，原点部の細片にのみ強い 
図15 本収縮物質の移動度キモグラム
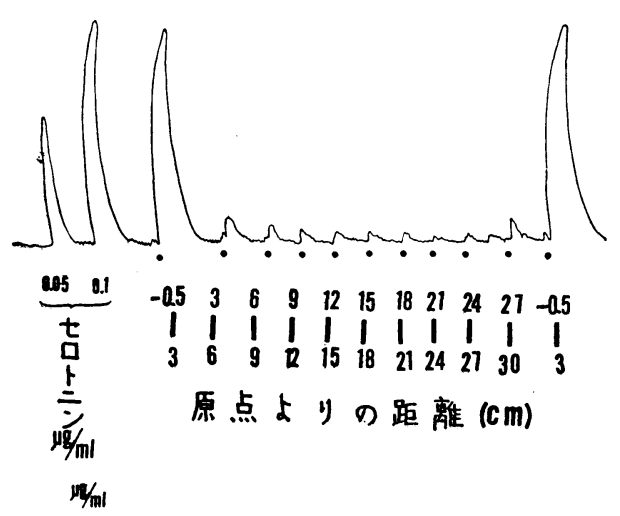

收縮を起し，他の細片では何等收縮を起さない. 師ち Rf は殆んぞ零である，比較する為にセロト ニンで同じく検討してみると， Rf た.

（5）小括及び考按

以上のことより本收縮物質の生じ方及び生化学 的性質より考察すると，本收縮物質は Gaddum 等のいう active polypeptidesのどれと最もよく 類似しているのであろうか.（VIII）で述べた如く, 本物質の生因から所謂 Plasma Kinin に属するも のであると考えたい。この生因から本物質は既に Vasopressin, Oxydocin, Cholecystokinin 及び Substance P とは異る. Vasopressin 及び Oxytocin の如き下垂体後葉ホルモンが増加するこ とは理論的にも考え難く, 更に Oxytocin は非透 析性である点からも本物質とは異る. Cholecystokinin, Substance P については, Cholecystokinin は未だ物質として取り出されていなくて, 生化学的性質は不明であるが, Substance P とは
同一物質ともいわれており， Substance P はぺ プシンで不活性されることより本物質とは異る. Pepsitensin, Pepsitocin 及び Pepsanurin は, 生因からは Plasma Kinin に属するが未だ不明 の点が多く，比較するに困難であるので一応除 外した。 又 Hypertensin も生因からは Plasma Kinin 属し，本物質の生成に類似しているが ペプシンによつて不活性化されることより本物質 とは異なるものと考えられる。

Kallidin, Bradykinin, Substance U 及びSubstance $Z$ の一群は，お互に非常によく類似し 全部同一物質ともいわれているが，中でも特に Kallidin と Bradykinin は現在同一物質である とする説62)147) の方が有力であるので，代表的な Bradykinin と本物質の生化学的性質を表 6 に示 した如く比較した。

Bradykinin は酵素による不活性化について は,トリプシンによつて不活性化されるとの說も あり, ペプシンによつては不活性化されないとさ れている. 又ペーパークロマトグラフィーでは,

Holdstock et a $\left.{ }^{i} 2\right)$ によれば Rf $=0.35$ という值 を報告しているが, Rocha e Silva et al ${ }^{11}$ によれ ば Rf 值は純度により異り純度が高くなれば $\mathrm{Rf}$ も大きくなり， $\mathrm{Rf}=0$ 0 0.52であるとしている. 以上により本收縮物質は，生化学的性質から $\mathrm{Br}$ adykinin に類似していることがわかるのである. 更に本物質を明らかにするためには，薬理学的性 質についての研究が不可欠である．例えば血圧作 用20)及び毛細血管透過性作用62)88)等であるが，こ れら実験には試料が純粋でなければならず、この 点に於て本物質の抽出物質が未だ純粋でないので

表 6 本收縮物質と Bradykinin の生化学的性質の比較

\begin{tabular}{|c|c|c|c|c|c|c|c|}
\hline & \multirow[b]{2}{*}{ 生 成 } & \multicolumn{3}{|c|}{ 酵素による不活性化 } & \multirow{2}{*}{ 熱耐性 } & \multirow[b]{2}{*}{ 透析性 } & \multirow[b]{2}{*}{ 移動度（ ） } \\
\hline & & 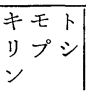 & トリプ & ペプシ & & & \\
\hline 本収縮物質 & 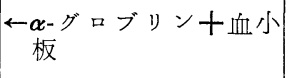 & + & tor- & - & + & + & 0 \\
\hline Bradykinin & \begin{tabular}{|l|}
$2^{2}$ グロブリソ+ \\
-Trypsin or Venom \\
of $\mathrm{B}$. jaravala
\end{tabular} & + & +or- & - & + & + & $\begin{array}{l}0 \sim 0.52 \\
\text { （純度による） }\end{array}$ \\
\hline
\end{tabular}


行つてはいない。

大伏在静脈内顆部から剔出した人静脈の收縮を みておるがこれがこのまま生体内の他の種々の 血管にあてはまるとは簡単に考えられないのは勿 論である. active polypeptides の末梢血管に対 する作用は色々であるが，Bradykinin, Kallidin 等は末梢血管には拡張性に働くといわれている 34).（III）の剔出人静脈の実験では，ヒスタミ ン, セロトニン, ノルアドレナリンは強い收縮を 示した．然しヒスタミンは毛細血管を拡張するこ とは衆知のことであり, 又最初 Vasoconstrictor として発見されたセロトニンは，その後血管部 位, 使用量, 動物の種類及び麻醉の方法等によつ て相異が大きく4)49)98)109)111), 血管收縮作用と拡張 作用の二相性を呈するとされている. F.J. Haddy et al（1957）50) はセロトニンは大血管は收 縮，小血管は拡張することさえ主張している. 又 セロトニンは毛細血管を拡張し, 毛細血管の透過 性を増加するといわれている120). 故に本收縮物質 は局所的には輸血部位の静脈壁平滑筋に働いてこ れを收縮させ, 全身的にも毛細血管に対して拡張 的に㗢くのではないかとも考えられているのであ る. 但し通常の手術時に使用される保存日数の比 較的短い保存血の輸血量では, 受血者体内中の血 液で本物質は稀釈され, 毛細血管の著明な拡張を 起すには至つていないのであろう。保存血輸血時 の最大欠点の一つとして, 原因について未だ結論 のでていない保存血大量輸血による出血傾向の問 題がある. 今迄にわかつている如く血小板やその 他の血液凝固因子の減少による因子は勿論である が，毛細血管收縮不全の一因に本物質が何かの役 割をはたしていないだろうかは，興味ある問題で あると考える。

\section{XI. 保存血流入速度遅延の対策}

保存血血漿中の收縮物質の生じ方は, 保存血中 に血小板が崩壊し，この崩壞した血小板が酵素的 に血嶈蛋白（ $\alpha$-グロブリン）に作用して收縮物質 であるポリペプチドを作るわけである，故に血 小板の崩壊を少くすれば本收縮物質の生じ方は少 くなるものと考えられ，特に（VII）に述べた如く
血小板破壞産物と $\alpha$-グロブリンの結合が早くな ければ，收縮物質の生じ方は更に少いと推定され る. 保存血中の血小板の崩壊は，採血時並びに保 存 3 日目で既に $2 / 3$ 以上の減少がみられるとされ ている19)47771)78)79)93)。これに対してnonwettable surface 採血嚗使用の A C D 加保存血は, 血小板 の崩壊が少いとされておる，J.L. Tullisis3) はあ る一部の血小板は，赤血球や白血球よりも寧ろ 長く保存されているとさえいつている．故に採血 時並びに保存中の血小板破壊を出来るだけ少くす る為に，(V) に述べた如くシリコン処理した採 血塨に，ポリエチレンチューブを通して重力法で 静かに採血した。同時に同じ供血者より普通採血 嚗に採血し，これらの20組の血液を $4{ }^{\circ} \mathrm{C} に$ 保存し て，手術時に同一患者に於いて両者の流入速度を 比較した，両者保存血の凝固物は 8 枚重ねのガー

図16 シリコン䭪及び普通墤採血保存血の流入速度 の比較

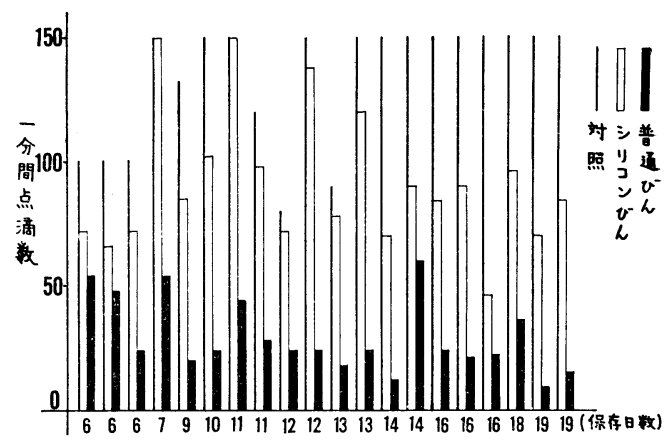

ゼでイルリガートル中に潇し，大伏在静脈内顆部 より輸血針又は静脈切開後カテーテルを捙入して 輸血し, 流入速度測定時は, イルリガートルの高 さは終始同じ高さに保たした。この保存血輸血の 前には予め対照として, 生食又は新鮮血で流入速 度を測定した。眓16に示すごとく，対照の生食又 は新鮮血で既に流入速度の非常に遲い例があり， 従つてシリコン嚗採血の保存血でも流入速度が遐 い例もあつたが，これは血管の細い皮下脂肪の多 い高年の女性に多くみられた。全体にシリコン嚗 の方が普通嚗に比較して, 全例とも流入速度がは るかに速かつた，師ち保存血流入度遲延の対策と 
図17 シリコン壜及び普通埕保存血血獎の剔出ダイ コクネズミ結腸収縮能キモグラム

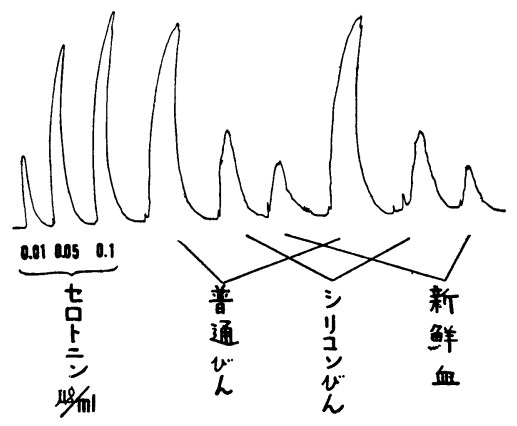

してシリコン嚗で採血し保存する本法は有効であ ると思われる。

更に両者血漿の剔出ダイコクネズミ結腸の收縮 能を比較すると, 全例に於いてシリコン嚗の方は 普通嚗の方よりも收縮能が $5 \sim 10$ 倍位も弱く, 明 らかに腸管收縮物質の産生が少い。図17は保存日 数10日の例を示したものである.なお両者血漿に よるこの二つの臨床実験とダイコクネズミ結腸收 縮実験より，保存血血漿中に生じて来る本收縮物 質による人静脈とダイコクネズミ結腸の收縮は, 平行することが逆に証明されるものと思われる。

両者保存血の血小板数については, 保存中に血 小板, 白血球及び赤血球が相互に粘着し合つて凝 塊を作り，その算定は困難であつて不正確になる ことは止むを得ない.シリコン壜では平均 36,00 0 , 普通嚗では平均 19,000 位で, 大体シリコン 嚗で 2 倍多く維持されている様である. 然し正常 では25〜40万ある血小板が普通嚗の方では勿論, シリコン䭪でも激減しているので, 単に血小板の 壞れ方がシリコン嚗の方でや>普通壜に較べて少 い位では，本現象の原因は充分に說明出来ない。 シリコン嚗と普通嚗の血小板数は, 例えば 3 週間 後では両者の差は少くなるが, 採血直後及び保存 初期にはかなり差があつて, 普通嚗では遙かに多 く破瓌されていると考えられるわけである。郎ち （VII）に述べた如く，本物質がぞの様に出来るか は採血後比較的早期にその運命がきまり，後はそ れが次第に増强されて行くものと考えられるので ある。

\section{XII. 総括及び考按}

保存血流入速度遲延現象の原因については, 従 来種々の說が報告されており,これらはいづれも 物理的乃至機械因子に着眼しておるのみであつた が，星川が保存血血墏中に輸血部位の静脈を收縮 させる血管收縮物質が生じこれが本現象の主因で あろうと推定した．著者はこの推定にもとづき， 保存血自体の性狀の変化に着眼して本現象を追究 して，保存血血漿中に血管收縮物質が生じて来る ことを明らかにし，更にこの收縮物質の生成，性 質並びにこの保存血流入速度遲延の臨床的対策等 を検討した。

まず保存血血漿は新鮮血血漿と違つて, 剔出人 静脈を強く收縮することを実証し，保存血血漿中 には血管壁平滑筋の能動的收縮を起す血管收縮物 質が存在することを確認した。文保存血血漿は新 鮮血血漿と違つて剔出ダイコクネズミ結腸をも剔 出人静脈の場合と同様に強く收縮することを見出 した。師ち本收縮物質の平滑筋作用は, 更に(V) 及び（XI）に於いても述べた如く，人静脈とダイ コクネズミ結腸に対してはほぐ平行するものであ つて，本收縮物質の研究を行つていく上に，平滑 筋材料として剔出ダイコクネズミ結腸を使用して 検討し得るわけで，且つ定量的測定も血管と較へ て容易に可能である.

保存血血漿中に生じ得る平滑筋收縮物質は, active polypeptides の一群と, これ以外の一群 とに大別して考えられるのである. 後者の一群を まず考察すると，アドレナリン，ノルアドレナリ ン, ヒスタミン及びアセチールコリンについて は, 剔出ダイコクネズミ結腸の特性並びに潅流液 中に加えられたアトロピンの実験条件によつて, いづれも本收縮物質とは区別され得た。 $\mathrm{K}+$ は保 存血血漿中に次第に増加するが，（V）の血液成 分分別試料のそれを熖光光度計で測定した結果, $\mathrm{K}^{+}$の増加と腸管收縮能の増強とは平行関係が見 出されないことより，本收縮物質ではないことが 証明出来る．血管收縮物質としてょく知られてい るセロトニンについては, 分光螢光測定法並びに 剔出ダイコクネズミ結腸を使用した生物学的測定 
法によつて実測した結果，保存血血漿中のセロト ニンは寧ろ減少し，更に（V）の血液成分分別試 料及び（VIII）の血漿蛋白分劃試料の中で, 腸管收 縮能の増強した試料のセロトニンはいづれも全部 減少し，更にL S Dによつて本收縮物質の腸管收 縮作用は阻止されないことより，本收縮物質はセ ロトニンでないことは更に明らかである。

本收縮物質の生成は（V）の血液成分分別試料 並びに（VII）の血漿蛋白分劃試料の実験より，血 小板破壞産物が酵素的に血漿蛋白の中の主とし て $\alpha$-グロブリンに作用して生ずるものと考えら れるが，この生成及び本收縮物質の蛋白分解酵素 による不活性化，熱耐性，透析性及びペーパー クロマトグラフィーの移動度等の生化学的性質 より，本收縮物質は Bradykinin 及び Kalliain に類似した active polypeptideミの一種と考えら れる．更に本收縮物質の性質を明らかにするため には, 薬理学的性質例えば血圧作用及び毛細血管 透過性作用等についての検討が必要であるが，こ れらの実験には試料が純粋でなければならず, 著 者の得たアルコール抽出物質を更に純粋化する必 要がある。

最後にこの保存血流入速度遲延の対策として, シリコン処理採血壜の使用が有効であることを述 ベたが，これはシリコン処理鎄の保存血の方が対 照の普通嚗のそれに較べて，血小板の破壊が少く 保存されていることによるのは勿論であるが, 特 にシリコン䭪が血小板の採血後短時間の破壊を可 及的に少くすることにその意義があるものと考え られる，郋ち本收縮物質の生成機序は（VII）に述 ベた如く，血小板破壊産物と $\alpha$-グロブリンを中 心とする血漿蛋白の結びつきが保存中の比較的早 期に行われ, 以後徐々に本收縮物質の生成を増強 するものと考えられるからである.最近諸外国で はガラス採血丵に代つて，プラスチックバッグの 使用が増えて来たが，この点からも実用的に有効 であると考えられる。

\section{XIII. 結 論}

保存血流入速度遲延の現象について, 臨床的並 びに実験的に研究し, 保存血血漿中に血管收縮物
質を生じて来ることがその原因であることを見出 し，この收縮について次の諸点を明らかにした。

1）保存血血漿は剔出人静脈を收縮し, 又ダイ コクネズミ結腸をも收縮させる。

2）保存血血漿中のこの收縮物質は, $\mathrm{K}^{+}$, ヒス タミン，アドレナリン，ノルアドレナリン，アセ チールコリン及びセロトニンなどではない.

3）この收縮物質は，破壊された血小板が $\alpha$ グロブリンを中心とする血漿蛋白分劃に作用して 生じた active polypeptides の一種で, 生化学的 性質からは Bradykinin 又は Kallidin に類似し ていると考えられる。

4）アルコール抽出法で, 保存血血漿より active polypepsideとして黄色の粗製物質を抽出し た。

5）この收縮物質の生成を少くするためには， シリコン処理暧で採血するのが有效なる一法であ つて，臨床的にかなり満足すべき結果を得た。

本研究は東宮待医星川光正博士，東大輸血部遠山博 博士との協同に上る処多く，尚教室主任清水健太郎教 授及び石川浩一助教授, 生化学教空紺野邦夫博士, 手 塚統夫学士，栄峑学教公中尾真博士，東大物性研究所 牧島研究室助手鞆津武工学博士, 当教室宮川静一郎学 士並びに森岡泰彦学士等から多大の御助力を賜った。こ 〉汇深く感謝する次第である.

\section{交献}

1) Andrade, S.D., Diniz, C.R. \& Rocha e Silva, M.: Arch. int. Pharmacodyn. 95 : 100, 1953.

2) Amin, A.H., Crawford, T.B.B. \& Gaddum, J.H.: J. Physiol. $126: 596,1954$.

3) Appelt, W.W. \& Ederstrom, H.E.: Angiology, $10: 153,1959$.

4) Armstrong, D., Dry, R.M.L., Keele, C.A. \& Markham, J.W.: J. Physiol, 117 : 701952.

5) Armstrong, D., Jepson, J.B., Keele, C.A. \& Stewart, J.W.: J. Physiol. $135: 350,1957$.

6) Beraldo, W.T.: Amer. J. Physiol. 171 : 371, 1952.

7) Bigelow, F.S.: J. Lab. Clin. Med. 43 : 759, 1954.

8) Blashko, H.: Pharmacol. Rev. 4 : 415, 1952.

9) Blashko, H. \& Hope, D.B.: J. Physiol, 122: 419, 1953.

10) Bowman, R.L., Caufield, R.A. \& Udenfriend, S.: Science, $122: 32,1955$. 
11) Brecher, G. \& Cronkite, E.P.: The Coagulation of Blood, Methods of Study. Chapter V Blood Platelets p. 41.

12) Cerletti, A. \& Rothlin, E.: Nature 176 : $785,1955$.

13) Cohn, E.J., Strong, L.E., Hughes, W.L., Mulford, D.J., Ashworth, J.N., Melin, M. \& Taylor, H.L.: J. Amer. Chem. Soc. 62 : 3396, 1940.

14) Cohn, E.J. et al.: J. Amer. Chem. Soc. $68: 459,1946$.

15) Corne, S.J. \& Graham, J.D.P.: J. Physiol. 135 : 339, 1957.

16) Correale, P.: J. Neurochem. 1 : 22, 1956.

17) Croxatto, H. \& Croxatto, R.: Science, 95 : 101, 1942.

18) Dalgliesch, C.E., Toh, C.C. \& Work, T.S.: J. Physiol, $120: 298,1953$.

19) De Gowin: Blood Transfusion p. 309, 1949.

20) Dekanski, J.: Brit. J. Pharmacol, 9 : 187, 1954.

21) Denstedt, O.F.: Blood Cells \& Plasma Protein, Tullis, T.L. 編集, Academic Pres. 1953.

22) Dodd, W.A. \& Daniel, E.E.: Circulation Res, $8: 451,1960$.

23) Ellis, M.E \& Grollman, A.: Endocrinology $44: 415,1949$.

24) Emanuel, D.A., Scott, J.B. \& Haddy, F.J.: Amer. J. Physiol, 197 : 637, 1959.

25) Erspamer, V.: Arch. exp. Path. Pharmakol, $196: 343,1940$.

26) Erspamer, V.: Acta pharmacol, $4: 213$, 1948.

27) Erspamer, V.: Arch. int. Pharmacodyn, $93: 293,1953$.

28) Erspamer, V.: Naturwissenshaften 40 : 318, 1953.

29) Erspamer, V.: J. Physiol $127: 118,1955$.

30) Erspamer, V.: J. Physiol $133: 1,1956$.

31) Erspamer, V.\& Asero, B.: Nature 169 : $800,1952$.

32) Euler, U.S. \& Gaddum, J.H.: J. Physiol, 72: $74,1930$.

33) Fänge, R.: Experientia $11: 156,1956$.

34) Fingl, E. \& Gaddum, J.H.: Fed. Proc. 12 : $320,1953$.

35) Frederick, S. \& Bigelow, M.D.: J. Lab. Clin. Med. $43: 759,1954$.

36) 藤田：日薬理誌, $50: 173,1954$.

37) Furchgott, R.F. \& Bhadrakom, S.: J. Pharmacol. exp. Therap, $108:$ 129, 1953.

38) Gaddum, J.H.: J. Physiol, $119: 363,1953$.

39) Gaddum, J.H.: J. Physiol, 121 : 15, 1953.
40) Gaddum, J.H.: Polypeptides which stimulate plain muscle E \& S Livingstone LTD. Edin. and Lond. 1955.

41) Gaddum, J.H. \& Hameed, K.A.: Brit. J. Pharmacol. $9: 240,1954$.

42) Gaddum, J.H. \& Paasonen, M.K.: Brit. J. Pharmacol, $10: 474,1955$.

43) Gaddum, J.H., Peart, W.S. \& Vogt, M.: J. Physiol. $108: 467,1949$.

44) Gaddum, J.H. \& Schild, H.: J. Physiol, 83: 1, 1934.

45) Gardner, F.H., Howell, O. \& Hirsch, E.O.: J. Lab. Clin. Med, 43 : 196, 1954.

46) Gomes, F.P.: $\quad$ Brit. J. Pharmacol, $10: 200$, 1955.

47) Gross, R. \& Staufenberg, E.: Klin. Wschr, $34: 142,1956$.

48) Gurevitch, J. \& Nelken, D.: Blood 11 : 924, 1956.

49) Haddy, F.J., Gordon, P. \& Emanuel, D.A.: Circulation Res, $7: 123,1959$.

50) Haddy, F.J., Fleishman, M. \& Emanuel, D. A.: Circulation Res, 5 : 247, 1959.

51) Hardisty, R.H. \& Stacey, R.S.: J. Physiol, $130: 711,1955$.

52) Helmer, OM.: Amer. J. Physiol, $188: 571$, 1957.

53) Helmer, O.M.: J. Lab. Clin. Med, $50: 737$, 1957.

54) Heymans, C. \& Bouckaert, J.J. \& Moraes, C.: Arch. int. Pharmacodyn, $43: 468,1953$.

55) Hilton, S.M. \& Lewis, G.P.: J. Physiol, $128: 235,1955$.

56) Hilton, SM. \& Lewis, G.P.: J. Physiol, $134: 471,1956$.

57) Hilton, S.M. \& Lewis, G.P.: J. Physiol, $144: 532,1958$.

58) 平井等 : 電気泳動法一理論と医学的応用 126 .

59) Hirose, K.: Arch. intern. Med, 21 : 604, 1918.

60) Hirsch, E.O. \& Gardner, F.H.: J. Lab. Clin. Med, $31: 638,1952$.

61) Hirsch, E.O. \& Gardner, F.H.: J. Lab. Clin. Med, $39: 556,1952$.

62) Holdstock, D.J., Mathias, A.P. \& Schachter, M.: Brit. J. Pharmacol, 12 : 149, 1957.

$63)$ 星川：日外会誌, $54: 265$, 昭 28 .

64) 星川：血液と輸血, 2 : 4, 昭31.

$65 ）$ 星川等：第15回日本医学会緿会会誌. 5021959

66) Humphrey, J.H. \& Toh, C.C.: J. Physiol, $124: 300,1954$.

67) Humphrey, J.H. \& Jaques, R.: J. Physiol, $124: 305,1954$. 
68) Janeway, T.C., Richardson, H.B. \& Park, E.A.: Arch. intern. Med. 21 : 565, 1918.

69) Jaques, R. \& Schachter, H.: Brit. J. Pharmacol. $9: 53,1954$.

70) Jesovier, H.S., Lipson, H.I. \& Brookly, N. Y.: Amer. Heart. J, $49: 770,1955$.

71) 加藤 : 輸血学, 247, 昭 26.

72) 川野：血液之輸血，5：147, 1958 .

73) Keller, R.: Experientia 13 : 112, 1957.

74) Keyns, G.: Blood Transfusion 388, The Technique of Blood Transfusion

75) 木村 : 内科, $2: 283$, 昭33.

76) Knox, W.E., Colowick, S.P. \& Kaplan, N.O. Methods in Enzymology, Vol. II. Academic Press, New York, 289, 1955.

77) 小林等: 濾紙電気泳動法の実際, 南江堂, 1956.

78) Kolmer, J.A.: Amer. J. med. Sci. 197 : $442,1939$.

79) Kolmer,J.A. \& Howard, M.: Amer. J. med. Sci. $200: 311,1940$

80) Ladua, JA. \& Awapara, J.: Science. 109 : 385, 1949.

81) Langemann, H. \& Kägi, J.: Klin. Wschr. 34: 237, 1956.

82) Langemann, H. \& Kägi, J.: Klin. Wschr. $34: 287,1956$.

83) Leonard, E.: Amer. J. Physiol. $189:$ 185, 1957.

84) Lewis, G.P.: J. Physiol. $140: 285,1958$.

85) Lozner. F.U. \& Taylor, F.H.L.: J. Clin. Invest, $21: 241,1942$.

86) Luduena, F.P. \& Brown, T.G.: J. Pharmacol. exp. Therap. $105: 232,1952$.

87) Margolis, J.: J. Physiol. 144: 1, 1958.

88) Miles, A.A. \& Miles, E.M.: J. Physiol. $118: 228,1952$.

89) 宮本等: 濾紙電気泳動シンポジゥム第 1 集

90) Mollison, P.L.: Blood Transfusion in Clinical Medcine, 2nd. edn. p. 286.

91) 森田等 : 最新医学, $11: 156$, 昭31.

92) Munoz, J.M., Braun-Menéndez, E., Fasciolo, J.C. \& Leloir, L.F.: Nature 44 : 980, 1939.

93) Mustard, J.F.: Brit. J. Haemat. 2 : 17, 1956.

94) 中尾等: 生化学, 31:526, 1959.

95) Neustrup, N. \& Milowsky, J.: N.Y. St. J. Med. $51: 2520,1951$.

96) O’ Kane, D.E. \& Gunsalus, I.C.: J. Biol. Chem. $170: 425,1947$.

97) Page, I.H.: Amer. Heart. J. 23, 336, 1942.

98) Page, I.H.: Physiol. Rev. 34 : 563, 1954.

99) Page, I.H. \& Helmer, O.H.: J. exp. Med. $71: 29,1940$.
$100)$ Pare, C.M.S., Sandler, M. \& Stacey, P.S.: Lancet, 1 : 550, , 1957

101) Prankerd, T.A.J.: Biochem. J. 64 : 209, 1956.

102) Pand, M. \& Reid, G.: Nature 168 : 385, 1951.

103) Rapoport, S.: J. Clin. Invest. $26: 591,616$, 629, 1947.

104) Rapport, M.M., Green, A.A. \& Page, I.H.: Science, $108: 329, .1948$.

105) Rapport, M.M., Green, A.A. \& Page, I.H.: J. Biol. Chem. 74 : 735, 1948.

106) Rapport, M.M., Gren, A.A. \& Page, I.H.: J. Biol. Chem., $176: 1237,1948$

107) Rapport, M.M., Green, A.A. \& Page, I.H.: J. Biol. Chem. $176: 1243$ (1948)

108) Rocha e Silva, M., Beraldo, W.T. \& Rosenfeld, G.: Amer. J. Physiol. 156 : 261, 1949.

109) Roddie, I.C., Shepherd, J.T. \& Whelan, R. F.: Brit.J. Pharmacol. 10 : 445, 1955.

110) Rosenthal, A.: Chirurg. $23: 411,1952$.

111) Rudolph, A.M. \& Paul, M.H.: Amer. J. Physiol. 189 : 263, 1957.

112) Schachter, M. \& Thain, E.M.: Brit. J. Pharmacol. $9: 1954$.

113) Schayer, R.W., Wu, K.Y.T., Smiley, R.L. \& Kobayashi, Y.: J. Biol. Chem. $210: 259$, 1954.

114) Schneider, H.: Med. Klin, 41 : 1086, 1951.

115) Shaw, E. \& Wolley, D.W.: J. Biol. Chem. $203: 979,1953$.

116) 啮沢：日本臨牀, $15: 56$, 昭 32 .

117) Shimizu K., Takayama, R., Tohyama, H. \& Hoshikawa, M.: Proc of 8th Congress of the International Society of Blood Transfusion (in the press)

118) Sjoerdsma, A., Smith, T.E., Stevenson, T. D. \& Udenfriend, S.: Proc. Soc. exp. Biol. Med, $89: 36,1955$.

$119)$ Snow, P.J.D., Lennard-Jomes, J.E., Curzon, G. \& Stace, y, R.S.: Lanciet ii: 1004, 1955.

120) Sollero, L., Page, I.H. \& Salmoraghi, G.C.: J. Pharmcol. exp. Therap. $117: 10,1956$.

121) Spector, W.G. \& Willoughby, D.A.: Nature $179: 318,1957$.

122) Stefanini, M., Chatterjea, J.B., Dameshek, W., Zannos, L. \& Santiago, E.P.: Blood 7 : 53, 1952.

123) Stowe, B.B. \& Thiaman, K.V.: Arch. Biochem-Biophys. 51 : 499, 1954.

124) Supek, Z. \& Milkovis, S.: Experientia 12 : 71, 1956.

125) 高山等：日輸会誌， $6: 313$, 砳 35 .

126) 田仲等：京府医大誌，55:87, 昭 29 .

127) Thompson, E.C.C., Hardwick, D.C. \& Wise- 
man, J.H.: J. Physiol. $140: 10,1958$.

128) Tobian, L., Martin, S. \& Eiler, S.: Amer. J. Physiol. $196: 998,1959$.

129) Tocantins, L.M.: Arch. Path, 23 : 850, 1937.

130) Tocantins, L.M.: Blood $1: 156,1946$.

131) Toh, C.C.: J. Physiol. $126: 248,1954$.

$132)$ 徳沢等 : 日輸会誌, $5: 240$, 昭 34 .

133) Tullis, J.L.: Blood $7: 891,1952$.

134) Tullis, J.L.: Blood, $8: 563,1953$.

135) Tullis, J.L.: Amer. J. med. Sci, 226 : 191, 1953.

136) Twarog, B.M. \& Page, I.H.: Amer. J. Physiol. $175: 157,1953$.

137) 上田等：臨床検査法，第 2 版， 321 .

138) Udenfriend., S, Weissbach, H. \& Clark, C. T.: J. Biol. Chem. $215: 337,1955$

139) Udenfriend, S., Bogdanski, D.F. \& Weissbach, H.: Science 122:972,1955.

140) Udenfriend, S., Weissbach, H. \& Brodie, B. B.: Methods of Biochemical Analysis, Vol. 6. 110 Edited by David Glick,

141) Vane, J.R.: Brit. J. Pharmacol. $12: 344$, 1957.
142) Welsh, J.H.: Arc. exp. Path. Pharmakol. $219: 23,1953$.

143) Welsh, J.H.: Nature, $173: 955,1954$.

144) Welsh, J.H. \& Taub, R.: Biol. Bull, 95 : 346, 1948.

145) Werle, E., Götz, W. \& Keppler, A.: Biochem. Z. 289 : 217, 1937.

146) Werle, E. \& Berek, U.: Biochem. Z. 320 : $217,1937$.

147) Werle, E. \& Berek, U: Biochem. 320 : 372, 1950.

148) Werle, E. \& Erdös, E.G.: Arch. exp. Path. Pharmakol. 223 : 234, 1954.

149. Wildy, P. \& Riddley, M.: Nature, 182 : 1801, 1958.

150) Wolley, D.W. \& Shaw, E.: J. Amer. Chem. Soc, $74: 2948,1952$.

151) 吉川等 : 医学の出々, $29: 204,1959$.

152) 吉川：臨床医化学, I 実験篇. 421, 昭34.

153) Zeller, E.A., Barsky, J. \& Berman, E.R.: J. Biol. Chem. $214: 267,1955$.

154) Zucker, M.B. \& Borrelli, J.: Ann. N.Y. Acad. Sci. $75: 203,1958$. 